\title{
Structure of the Earth's crust of the Eastern Rhodopes (Southern Bulgaria) from the regional deep reflection seismic profile Ivaylovgrad-Ardino
}

\author{
Khrischo Khrischev ${ }^{1}$, Stefan Shanov ${ }^{2}$, Stefka Pristavova ${ }^{3}$, Yotzo Yanev ${ }^{2}$ \\ ${ }^{1}$ Bulgarian Geological Society, Acad. G. Boncev Str., Bl. 24, 1113 Sofia, Bulgaria \\ ${ }^{2}$ Geological Institute, Bulgarian Academy of Sciences, Acad. G. Boncev Str., Bl. 24, 1113 Sofia, Bulgaria; \\ e-mails: s_shanov@abv.bg; yotzo_yanev@yahoo.com \\ ${ }^{3}$ Department of Mineralogy and Petrography, University of Mining and Geology "St Ivan Rilski”, 1700 Sofia, Bulgaria; \\ e-mail: stprist@mgu.bg (corresponding author)
}

(Accepted in revised form: March, 2020)

\begin{abstract}
This paper presents a geological interpretation of the deep seismic profile Ivaylovgrad-Ardino, which was published in 1996. Four plates are distinguished according to their seismic features that build up the Eastern Rhodope Terrane. They have a total thickness of 22-24 km and layered structures with suboceanic character. The lower two plates $(1,2)$ are westward obducted on the Rila-Western Rhodope Terrane, forming one obduction complex. Plate 3 is probably also a part of the obduction complex. Plate 4 is thrust southward on all plates. A Kobilino Crypto-dome, comprising Plates 1 and 2 and covered discordantly by the third one, is found at the eastern part of the profile at $7-7.5 \mathrm{~km}$ depth. The two lower plates do not appear on the surface, but some ultrabasic to basic bodies are supposed to be parts of them, rising as tectonic slices. The Plate 3 is revealed on the surface at the eastern part of the seismic profile (east of Avren Fault), and is built up mainly by the Pre-Rhodopean Supergroup metamorphic rocks, respectively from the seismically indistinguishable Upper and Lower Allochthon. The Plate 4 appears mainly at the western end of the profile (between Mishevsko Village and Ardino Town), and is built up by the metamorphic rocks of the Rhodopean Supergroup from the Startsevo Lithotectonic Unit (or Middle Allochthon). Five fault and shear zone systems of different ages are distinguishable in all plates. Transparent areas in the plates are interpreted as magma chambers of the Paleogene volcanoes, others as Upper Cretaceous and Paleogene (?) plutons. Because these magmatic chambers are located in the sub-oceanic crust, both intermediate and acid Paleogene volcanics have isotopic characteristics similar to those of the metasomatized mantle.
\end{abstract}

Khrischev, K., Shanov, S., Pristavova, S., Yanev, Y. 2020. Structure of the Earth’s crust of the Eastern Rhodopes (Southern Bulgaria) from the regional deep reflection seismic profile Ivaylovgrad-Ardino. Geologica Balcanica 49 (1), 3-30.

Keywords: Eastern Rhodope Terrane, obduction, Mohorovichich Discontinuity, crypto-dome, schizosphere-plastosphere, Paleogene volcanism.

\section{INTRODUCTION}

The regional deep seismic profiling IvaylovgradArdino was made in accordance with the longterm program "Geological structure and mineral resources of the Eastern Rhodopes" of the former Geology and Mineral Resources Committee. It was carried out by Geology \& Geophysics Corporation, Bulgaria. The fieldwork for deep seismic profiling crossing the structures of the Eastern Rhodope
Mountains (Bulgaria) started in 1993 and was finalized in 1995. The leading investigator, Dr A. Velev, outlined the main results, whose goal was to "introduce [...] the methodology of exploration and analysis of the wave pattern of the seismic profiles as a basis for their upcoming geological interpretation" (Velev, 1996). The regional profile consists of three parts, respectively named as profiles IR $1 \mathrm{a}$, IR $1 \mathrm{~b}$ and IR 1c (Fig. 1). On the main profile (IR 1c), four macro layers (three horizontal and one inclined) 


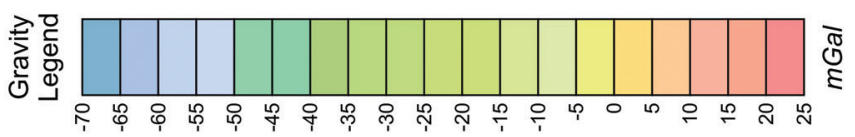

.1:

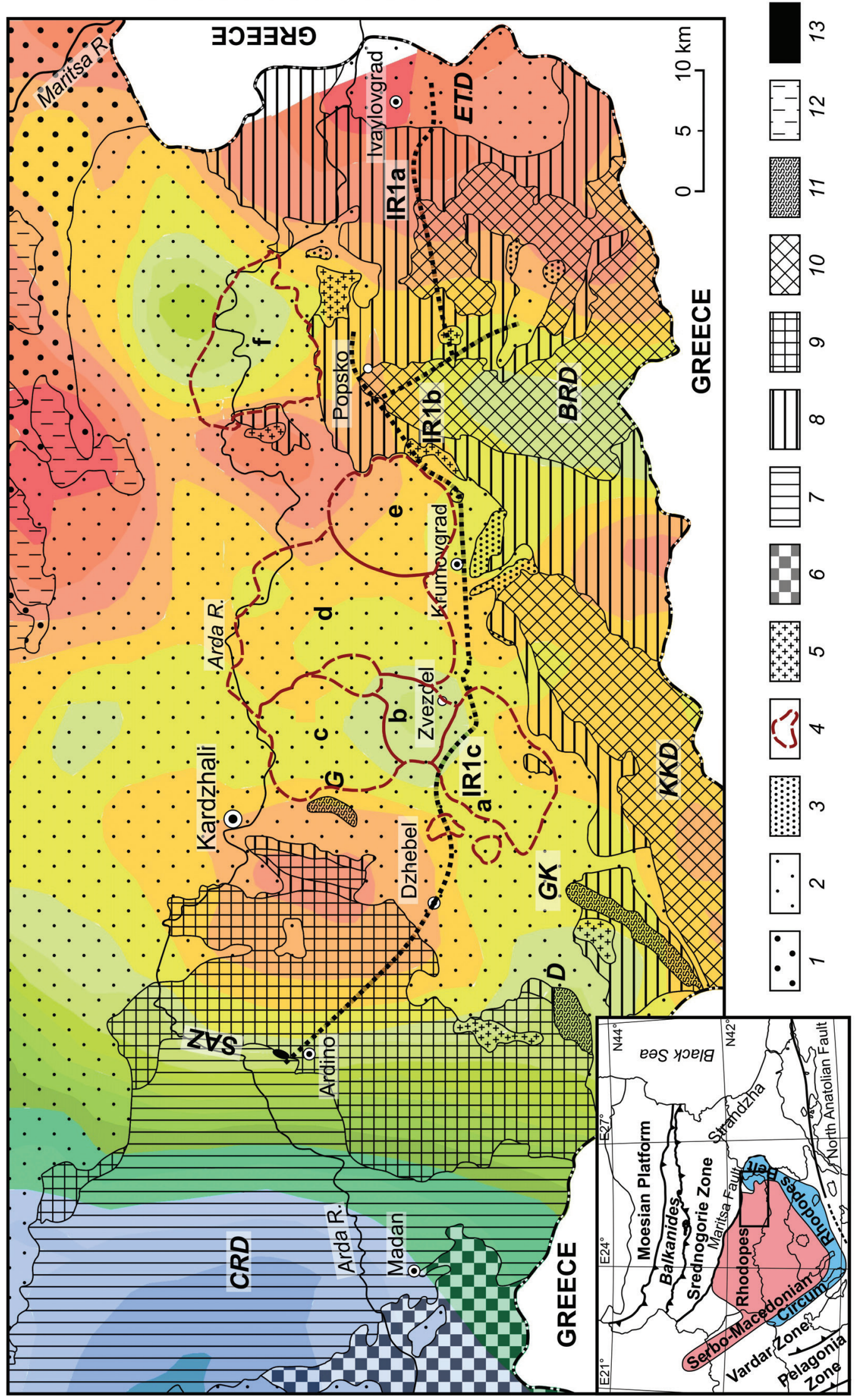


Fig. 1. Geological scheme of the lines of the deep seismic profiles in the Eastern Rhodopes and the Bouguer gravity anomaly field (in colors). Inset according to Bonev et al. (2013a). Legend: 1 - Neogene-Quaternary cover; 2 - Paleogene volcanics and sediments (ETD - Eastern Thracian Depression); 3 - Upper Cretaceous-Paleocene (?) sediments: Shavara and Kandila formations; 4 - Paleogene intermediate volcanoes with acid differentiates: a - Zvezdel, b - Paleo-Zvezdel, c - Dambalak, d - Sveti Iliya, e - Irantepe, f - Madzharovo; 5 - Upper Cretaceous and Paleocene granitoids; Rila-Western Rhodope Terrane (CRD - Central Rhodope Dome): 6 - Middle Allochthon (Madan Lithotectonic Unit); 7 - Lower Allochthon (Arda lithotectonic units); SAZ Startsevo-Ardino Shear Zone (after Jahn-Awe et al., 2012). Eastern Rhodope Terrane (KKD - Kesebir-Kardamos Dome, BRD Byala Reka Dome): 8 - Upper Allochthon (Kardzhali, Krumovitsa, and Divisil lithotectonic units) and Uppermost Allochthon (Mandritsa Lithotectonic Unit), 9 - Middle Allochthon (Startsevo and Borovitsa lithotectonic units), 10 - Lower Allochthon (Byala Reka and Kesebir lithotectonic units). 11 - ultramafic bodies (“slices”): G - Gledka, D - Dobromirtsi, GK - Golyamo KamenyaneYakovitsa; 12 - Thracian lithotectonic unit (Harmanli block); 13 - Ardino “mélange”; 14 - lines of the seismic profile (segments IR 1a, IR 1b and IR 1c). Colors represent the intensity of the Bouguer gravity anomalies, analytically recalculated for $15 \mathrm{~km}$ level after Ivanova et al. (2002b) (in the right - the scale in mGal from 25 to -70). Note: the names of the lithotectonic units are according to Sarov et al. (2004), Sarov (2012), Jahn-Awe et al. (2012) and the geological maps of Bulgaria in scale 1:50 000; names of the allochthon units after Burg et al. (1996). The limits of the lithotectonic units are given schematically according to Burg et al. (1996), Sarov et al. (2004), Bonev et al. (2010a), Sarov (2012) and Jahn-Awe et al. (2012).

were defined and described by Velev et al. (1995; 1996). Later, Velev (1996) considered this complex of macro layers to be obducted on the Central Rhodope Dome.

The information on the used data-processing methods was additionally reported by Gulmezova and Velev (1999). The geological and tectonic interpretations were based entirely on qualitative considerations of the seismic reflection time-scaled cross-section. Nevertheless, these publications showed that important new re-evaluation of the existing tectonic models for this part of the Balkan Peninsula needs to be done.

The migrated deep (metric) cross-section of the profile IR 1c (Popsko-Ardino) was assigned to us by A. Velev for geological interpretation in connection with the preparation of the monograph Geology of Bulgaria. Because the monograph has not been completed, the geological interpretation of this profile was published separately, significantly later (Khrischev and Shanov, 2017; Khrischev et al., 2017). In the present paper, all sections of the deep seismic profile (a, b, c) are considered in detail. The bases of IR 1a and IR 1b are borrowed from the publication of Velev (1996), where they are migrated in the time scale.

The main goals of this study are geological interpretation of the structure of the Earth's crust of the Eastern Rhodope Terrane, using deep seismic reflection profiling, through separation and characterization of the geological bodies (plates) and shear zone systems on the basis of seismic waves' characteristics; correlation of the obtained information with the surface-data using the geological map of
Bulgaria in scales 1:100 000 (with lithostratigraphic units) and 1:50 000 (with lithotectonic units); comparison of these data with other geophysical information especially with gravimetric ones (Ivanova et al., 2002; Trifonova et al., 2013); and clarification of the relation between the deep geological structure and the Paleogene magmatic activities. The obtained results of the study underline the conceptual significance of deep seismic profiling and also allow other geological interpretations.

\section{METHODOLOGY OF THE SEISMIC PROFILING}

The regional crooked deep seismic reflection profile IR1 was executed using the so-called COCORP Technique (Consortium for Continental Reflection Profiling), first used in the USA in 1970s for studying the deep Earth's crust structures (Velev, 1996). Seismic reflection lines were recorded by 240 -channel equipment MDS-16, a sample rate of $4 \mathrm{~ms}$ and a length of $16 \mathrm{~s}$. The geophone array spacing (a group of 18 geophones) was $50 \mathrm{~m}$. Four 16-ton vibroseis engines were operating at $100 \mathrm{~m}$ intervals, yielding nominal 60-fold data (Gulmezova and Velev, 1999). The study of the weathering low-velocity zone up to level +150 m was done using the uphole method. The holes were irregularly situated along the profile line at a distance from $1 \mathrm{~km}$ to $7 \mathrm{~km}(2.5 \mathrm{~km}$ in average) and their depth varied from $12 \mathrm{~m}$ to $60 \mathrm{~m}$.

The data processing (according to Velev, 1996, and Gulmezova and Velev, 1999) was done using the ProMAX software based on RISC 6000 system (Geology \& Geophysics Corporation, Bulgaria). 


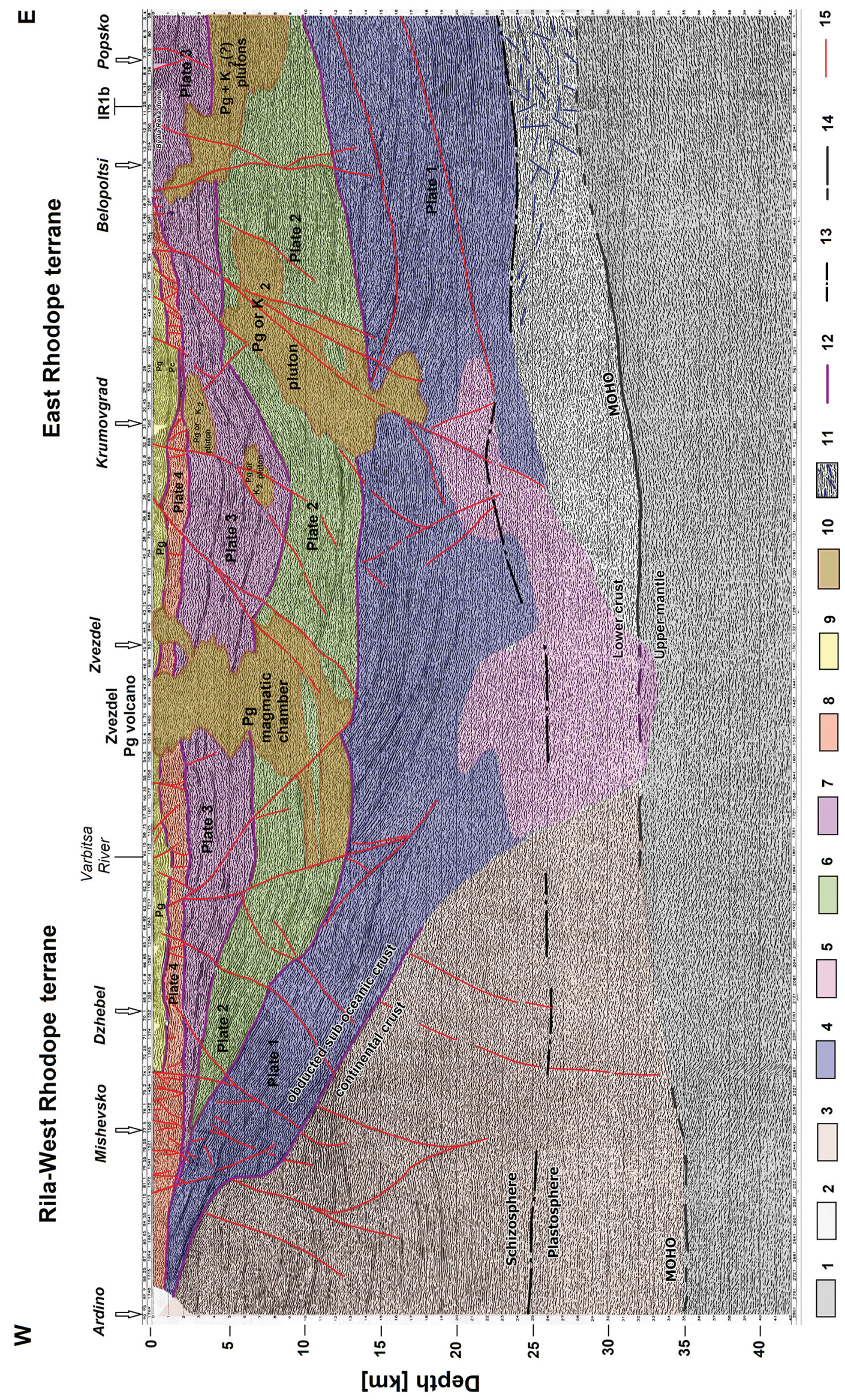


Fig. 2. Geological interpretation of the deep seismic profile, segment IR 1c. Legend: 1 - Upper mantle; 2 - Lower crust. Terranes and seismic plates in the Upper crust (the grey lines in the plates are indicative of seismic reflections): 3 - Rila-Western Rhodope Terrane (continental crust); Eastern Rhodope Terrane (sub-oceanic crust): 4 - Plate 1; 5 - Mushroom-shaped seismically transparent area (probable mantle heating of the Lower crust and base of Plate 1); 6 - Plate 2; 7 - Plate 3; 8 - Plate 4. 9 - Paleogene cover; 10 - Paleogene magmatic chambers and plutons ( $\mathrm{K}_{2}$ and Pg); 11 - area of "crossed" seismic reflections in the core of the Kobilino Crypto-dome. 12 - plate boundaries; 13 -schizosphere/plastosphere boundary in the Lower crust (following Scholtz, 1988). 14 - discontinuity of Mohorovichich (MOHO); 15 - some faults (all types are represented in Fig. 8). Note: no vertical exaggeration.

Different types of velocity analyses, residual static corrections and pre-stack and post-stack migrations were tested. 2D Crooked line geometry method was applied. The geometry of the field spreads was used for computing and displaying the scatter map of all Common Middle Points (CMP) and to select the average CMP line. The seismic section was obtained by stacking in a single $800-\mathrm{m}$ wide strip including near $90 \%$ of the total CMPs. Residual static correction improved additionally the quality of the final time-scaled cross-section.

Velocity inhomogeneities and their important variations in the Earth's crust were also revealed by the P-waves' arrival times from local earthquakes (Botev et al., 1988; Botev and Spassov, 1989). According to these analyses, at the depth interval between $6 \mathrm{~km}$ and $30 \mathrm{~km}$ beneath the Rhodope, the average $\mathrm{P}$ velocity is from $5.5 \mathrm{~km} / \mathrm{s}$ to $6 \mathrm{~km} / \mathrm{s}$.

The present study uses the transformed in kilometric scale deep reflection picture of the crosssection IR 1c, which was provided by A. Velev, and keeps the above-mentioned general model (Khrischev and Shanov, 2017; Khrischev et al., 2017) for quantitative interpretation of the geometrical characteristics of the crossed tectonic structures and their geological infilling.

The resolution of the velocity analysis is low and the stacking quality for deep reflections was reported to be weakly varying in the case of large-scale velocity changes (Gulmezova and Velev, 1999). The average and interval crustal velocities $V_{p}$ for the depth migration were deduced by averaging data obtained from the regional DSS (Deep Seismic Sounding) profiles Petrich-Nikopol (Volvovski et al., 1985; Dachev, 1988) and Ruse-Madan (according to Velev, 1996). For kilometric scale transformations of the structures drawn on the double-time cross-sections along profiles IR $1 \mathrm{a}$ and IR $1 \mathrm{~b}$, the average $V_{p}$ of $6 \mathrm{~km} / \mathrm{s}$ was applied.

The transformation of the gravity field at the level of 15th $\mathrm{km}$ above the surface (Ivanova et al., $2002 \mathrm{~b}$ ) gives priority to the intensity of the Bougu- er anomalies from deeper geological bodies and reduces the effect of the near-surface anomalies. Consequently, valuable information about the deep structures of the Earth's crust can be obtained (Fig. 1) and correlated with the structures detected by the seismic profiling.

\section{EARTH'S CRUST TYPES ACCORDING TO THE REGIONAL DEEP SEISMIC PROFILE}

The two terranes (tectonic units according to Dabovski et al., 2002), the Rila-Western Rhodope (with the Central Rhodope Dome as one of its elements) and the Eastern Rhodope, described on the surface are clearly distinguished in depth through seismic reflection on the basis of transparency, amplitude, resistance and frequency of reflectors, position at the Mohorovichich Discontinuity, as well as on the available gravimetric and magnetic data (Ivanova et al., 2002b; Trifonova et al., 2013). Two types of Earth's crust have been differentiated in the first geophysical interpretations (Velchev et al., 1971, and references therein). They were determined as continental and sub-oceanic types by Velev (1996) and others.

\section{Continental Earth’s crust}

This type of Earth's crust builds up the Central Rhodope Dome (CRD). The eastern part of the dome crops out in the western part of the investigated seismic profile IR 1c, where there is a wide development of gneisses and granite-gneisses on the surface. In this part of the profile IR 1c (Fig. 2), the seismic record is characterized by a high degree of transparency in the limited or larger areas, the presence of unclearly segmented areas separated without clear boundaries that can be assumed to represent the framework of the granite protoliths. In the middle part of the crust in this area, the reflections are more expressive and precise in the eastern di- 
rection and their convergence and wedging with a tendency to the east direction suggests belonging to a continental margin. In addition, they go slightly downward (Fig. 2), which could be considered an effect of the exhumation of the metamorphic core of the CRD. The seismic reflections in the deeper levels of the profile also underline this tendency. The western end of the profile IR lc (the area of Ardino) is clearly situated on the eastern edge of the large negative anomaly of the gravity field in Bouguer reduction (Fig. 1), related to the Rila-Western Rhodope Terrane.

\section{Sub-oceanic Earth’s crust}

This crust in the Eastern Rhodopes is characterized by "mixed" geological features on the surface: presence of continental and oceanic basic and ultrabasic protoliths (e.g., Velchev et al., 1971) and the higher values of the gravitational field (Ivanova et al., 2002b; Trifonova et al., 2013, and references therein).

According to the seismic record in the profile IR1 c, the features of the sub-oceanic crust are well registered in depth: the domination of well-distinguished layering and high reflectance of the boundaries with significant spatial sustainability. Along with this, there are also signs of disharmony and internal wedge-outs, some of them possibly related to the primary heterogeneity or magmatic processes. The structure of the Earth's crust is complicated by the widespread development of shear zones, well expressed also by the seismic diffraction. The larger areas with a transparent crust are associated with the plutons and the magma chambers of the Paleogene volcanism and probably allochthonous plates of older magmatic protoliths, some of them granites (?).

As a result of our study, four plates of the metamorphic rocks in the sub-oceanic crust are distinguished beneath the Tertiary cover, different from the macro layers of Velev et al. $(1995,1996)$ and Velev (1996).

\section{CHARACTERISTICS OF THE SEISMIC PLATES}

\section{Plate 1}

This plate is traced as a continuous layer in all three profiles (IR 1a, IR 1b and IR 1c) (Figs 2-4). The lower boundary has a variable character in the different parts of the profile IR 1c. In its westernmost part, the plate obducts the continental crust of CRD (Velev, 1996) and the lower boundary is sharp, representing a fault plane (line in the plane of the profile). Near the surface, only the uppermost part of the plate is developed, and both boundaries, the lower and the upper, are sub-horizontal here and the plate does not crop out on the surface (Figs 2, 5). In the middle part, the lower boundary with the Lower crust is unclear, because the Lower crust there is characterized by a high degree of transparency in the seismic record. It is complicated by deep penetrating faults, which deform the lower levels of the plate. The lower boundary is traced by a shear zone at a depth of $24 \mathrm{~km}$, marking the contact with the plastosphere. It separates a thin, horizontally layered crust on the top from an interval with predominantly short and low-amplitude reflections.

In general, the seismic record of Plate 1 in profile IR 1c marks a clear parallel, horizontal layering with high amplitude, frequency and spatial sustainability of the reflections that are specific to the wide spaces of an abyssal ocean bottom. The parallel layering at some intervals becomes less expressive in the eastern part of the profile IR 1c, where an unclear oblique system of reflections is determined. Here, the shear zones oriented close to the planes of stratification have wide development.

The seismic patterns are quite different in the satellite sub-meridional profile IR 1b (Fig. 3). Two parts are distinguished here in the interval corresponding to Plate 1 in the profile IR 1c (15-22 km), separated by an inclined fault. The upper part of the plate is finely horizontally laminated, with high amplitudes of reflections. Its plane parallelism is complicated in places by rare oblique and shorter reflections. The lower part consists of crossed reflections marking the lower part of the Kobilino Crypto-dome (see below).

In the profile IR 1a (Fig. 4), the layering is more expressive, with higher amplitude and spatial sustainability. The seismic pattern outlines one dome structure named by us the Kobilino Crypto-dome. This structure does not crop out on the surface and its highest part is situated at depth $7.0-7.5 \mathrm{~km}$. This structure is described in section "Tectonic structures".

Plate 1 is covered by Plate 2 and, at the western part of profile IR 1c, directly by Plate 3 and mainly Plate 4 (Fig. 5). The upper boundary is sharp, marked by an expressive shear zone with a distinctive discordance of the reflections on both plates in many places on the profiles IR $1 \mathrm{c}$ and IR $1 \mathrm{a}$. The angular discordance is well expressed in the western end of the profile IR 1c. The upper boundary is crossed by plutons in the eastern part of profile IR $1 \mathrm{~b}$ and in the profile IR $1 \mathrm{a}-$ an indication of the older age of the obduction.

The thickness of Plate 1 cannot be exactly estimated in the western part of the profile IR 1c due to 


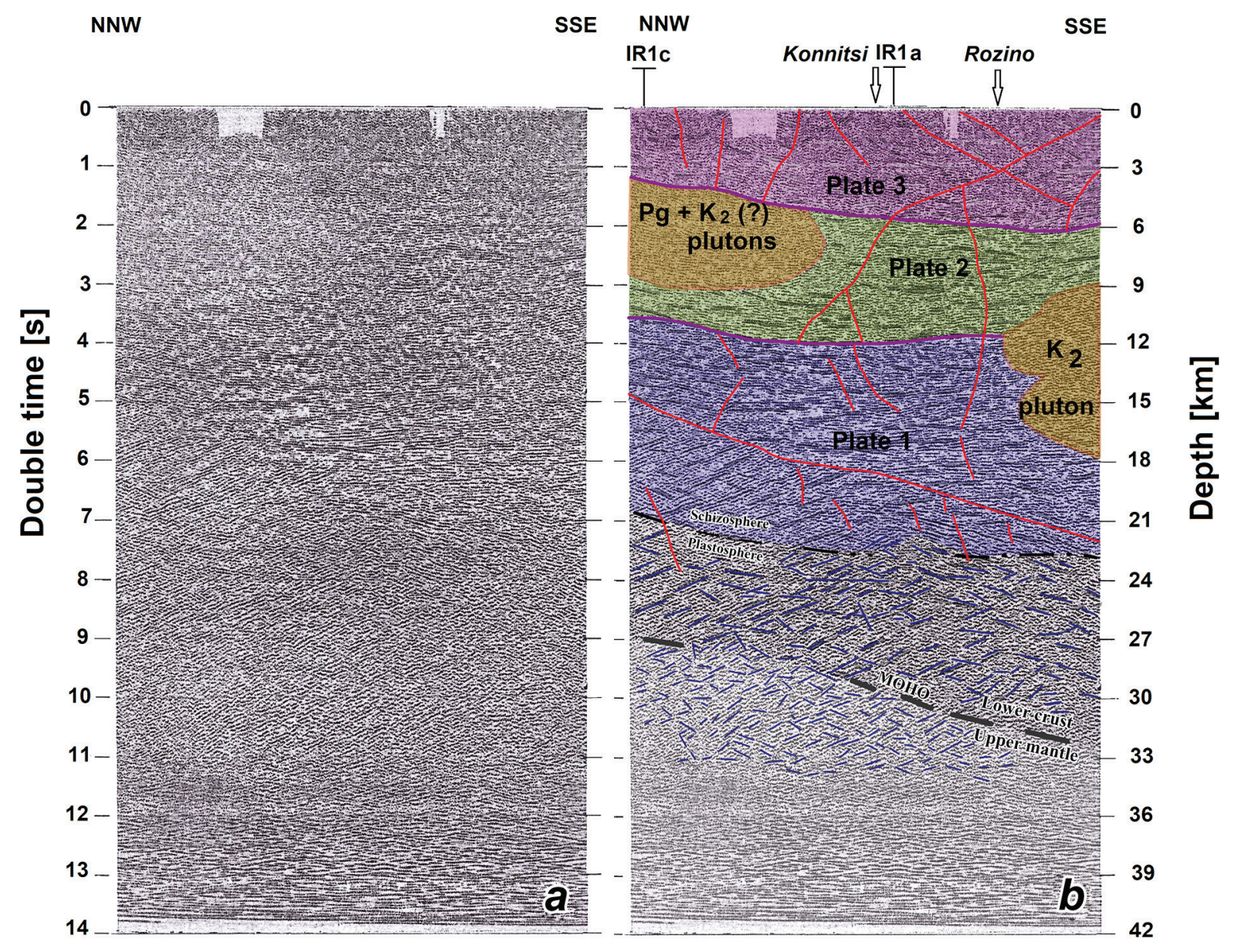

Fig. 3. Deep seismic profile, segment IR 1b: a) migrated seismic section along the profile (taken from Velev, 1996); $b$ ) geological interpretation. The legend is the same as in Fig. 2. Note: no vertical exaggeration.

the unclear lower boundary, but it reaches a maximum of $6 \mathrm{~km}$. It increases up to $12 \mathrm{~km}$ in the middle part of the profile and maximum values of $26 \mathrm{~km}$ are registered in profile IR 1a due to the Kobilino Crypto-dome.

\section{Plate 2}

Plate 2 is not exposed on the surface due to its shearing by the upper Plate 3 , especially expressive in the westernmost part of the profile IR 1c, where this shear zone discordantly cuts different levels of Plate 2. The boundary is not so clear to the east as a result of the concordance of the reflections on both sides and interruption in some places from plutons (i.e., in the profile IR 1a).

The thickness of Plate 2 is highly variable: from entirely wedging to the west and up to $7 \mathrm{~km}$ in the eastern part of the profile IR 1c and profile IR $1 \mathrm{~b}$ (Figs 2, 3), and from $7 \mathrm{~km}$ to $1.5 \mathrm{~km}$ in the profile
IR 1a, where it covers the Kobilino Crypto-dome (Fig. 4).

Plate 2 has a complex internal structure. The pattern is similar to that of Plate 1 , tracing a clear layering of parallel and spatially developed reflections. They are almost concordant to the boundary of Plate 1 in the westernmost part of the profile IR 1c (Fig. 2) and its inclination indicates movement to the west, despite the faulting nature of the boundary. The layering becomes more inexpressive gradually to the east with a presence of wedging reflection sites, resembling progradation structures dipping to the west. It allows us to presume the presence of a continental slope foot here. In the eastem part of the profile IR 1c, Plate 2 is characterized by a lower degree of layering. Its heterogeneity is preserved in both satellite seismic profiles where small diffraction areas are presented. Three plutons (see section "Igneous bodies") cross the plate in the eastern part of IR 1c and IR 1b (Figs 2, 3) and make it difficult 

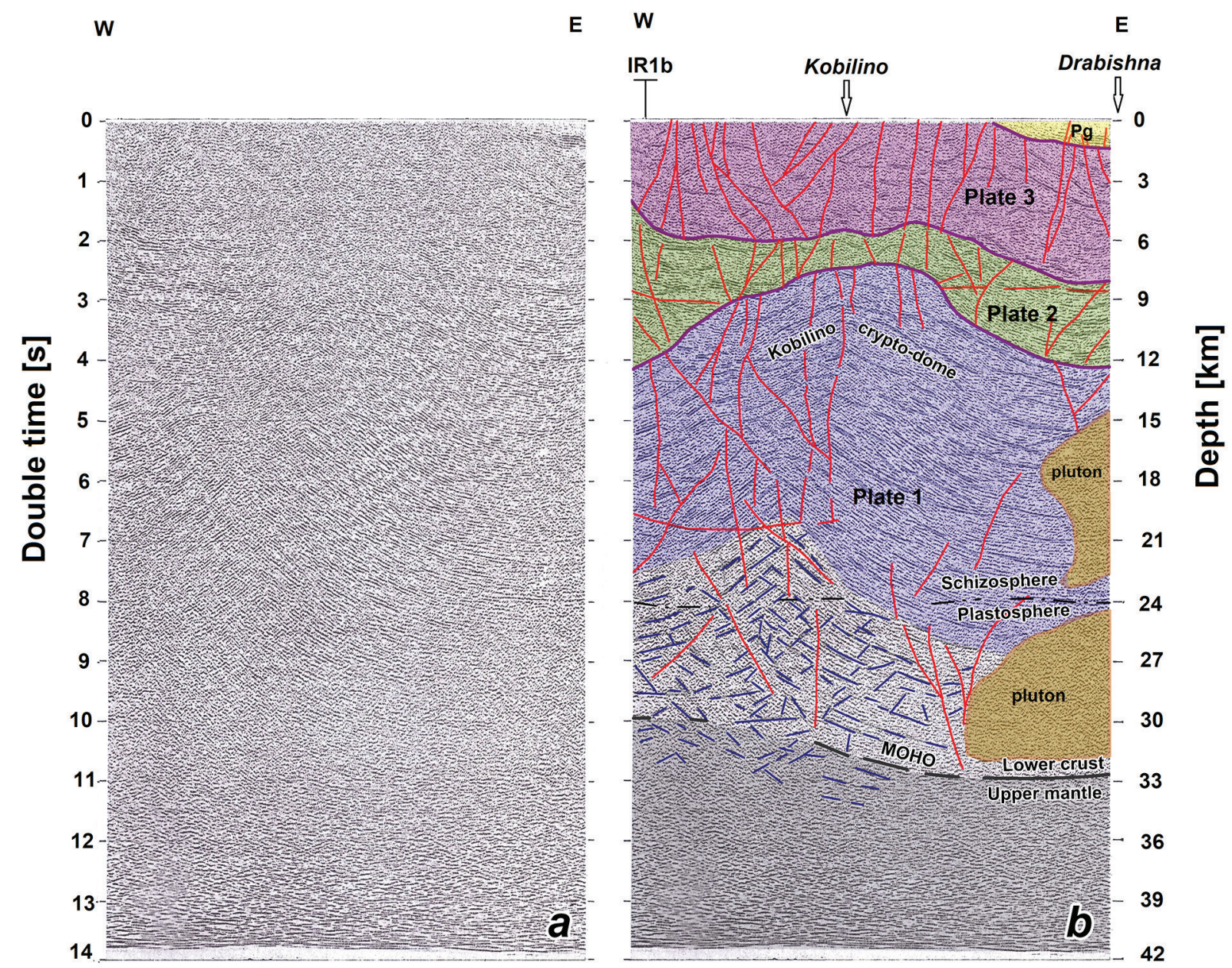

Fig. 4. Deep seismic profile, segment IR 1a: a) migrated seismic section along the profile (taken from Velev, 1996); b) geological interpretation. The legend is the same as in Fig. 2. Note: no vertical exaggeration.

to trace the plate. In the profile IR 1a (Fig. 4), the layering completely disappears above the top of the Kobilino Crypto-dome, where the thickness of the plate is reduced.

\section{Plate 3}

Plate 3 is traced along the entire length of all three seismic profiles, except in the westernmost part of profile IR 1c, where Plate 4 is in contact with Plate 1 (Figs 2, 5). Plate 3 is revealed on the surface in the eastern end of the profile IR 1c (the region of Popsko and Belopoltsi villages - Fig. 6), as well as in both satellite profiles IR 1a and IR 1b. It is covered by Plate 4 , and this contact has a thrusting nature to the west of Belopoltsi Village (see below).

The thickness of Plate 3 is highly variable, with a maximum of $7 \mathrm{~km}$ below the town of Krumovgrad. The cross-section here is the most complete, including the upper levels that are cut off by Plate 4 in other parts of the seismic profile. The gradual reduction of the thickness is up to $3.5 \mathrm{~km}$ to the west. On the satellite profiles IR $1 \mathrm{a}$ and $1 \mathrm{~b}$, the thickness reaches up to $6 \mathrm{~km}$.

Plate 3 is characterized by a more unclear layering, with expressive and widely distributed reflected boundaries in a large interval composed of short, often divergent and even chaotic reflections, especially in the profiles IR 1b (Fig. 3) and IR 1a (Fig. 4). These profiles cross the eastern part of the Byala Reka Dome that is strongly tectonically reworked by faults. Several synforms are observed in the northwestern part of profile IR 1b; one of them (east of Konnitzi Village) corresponds to the synform built of the metamorphic rocks of the Chepelare Formation (Kozhukharov et al., 1992). Only in the profile IR 1c, there are the basal reflections parallel to the lower boundary of the plate. In its easternmost part (Fig. 6), the periclinal end of the Byala Reka Dome is slightly visible. 


\section{Plate 4}

This plate is established only in the profile IR 1c and occurs on the surface in both end parts between Ardino Town and Mishevsko Village in the western end (Fig. 5) and between Chal and Belopoltsi villages in the eastern one (Fig. 6). Due to the development of a diffraction zone at the western part of the profile, the outlet itself is not confirmed very well.

The lower boundary is a thrust sub-horizontal zone, marking clear discordance with the lower plates, especially west of the town of Dzhebel. Ac- cording to the existing data (Burg et al., 1996; Bonev et al., 2013a, and the geological maps of Bulgaria in scale 1:50 000), the thrusting is in the southward, i.e., perpendicular to the obduction. Plate 4 is covered by Paleogene rocks and is crossed by plutons and Paleogene igneous rocks.

The thickness of the plate is significantly smaller compared to the lower plates and relatively constant from $1.0 \mathrm{~km}$ to $1.8 \mathrm{~km}$. Only in the region of Krumovgrad Town Plate 4 was eroded by the Tertiary basin (Figs 2, 7). Clear layering (perhaps because of its small thickness), which is expressed by a spatial
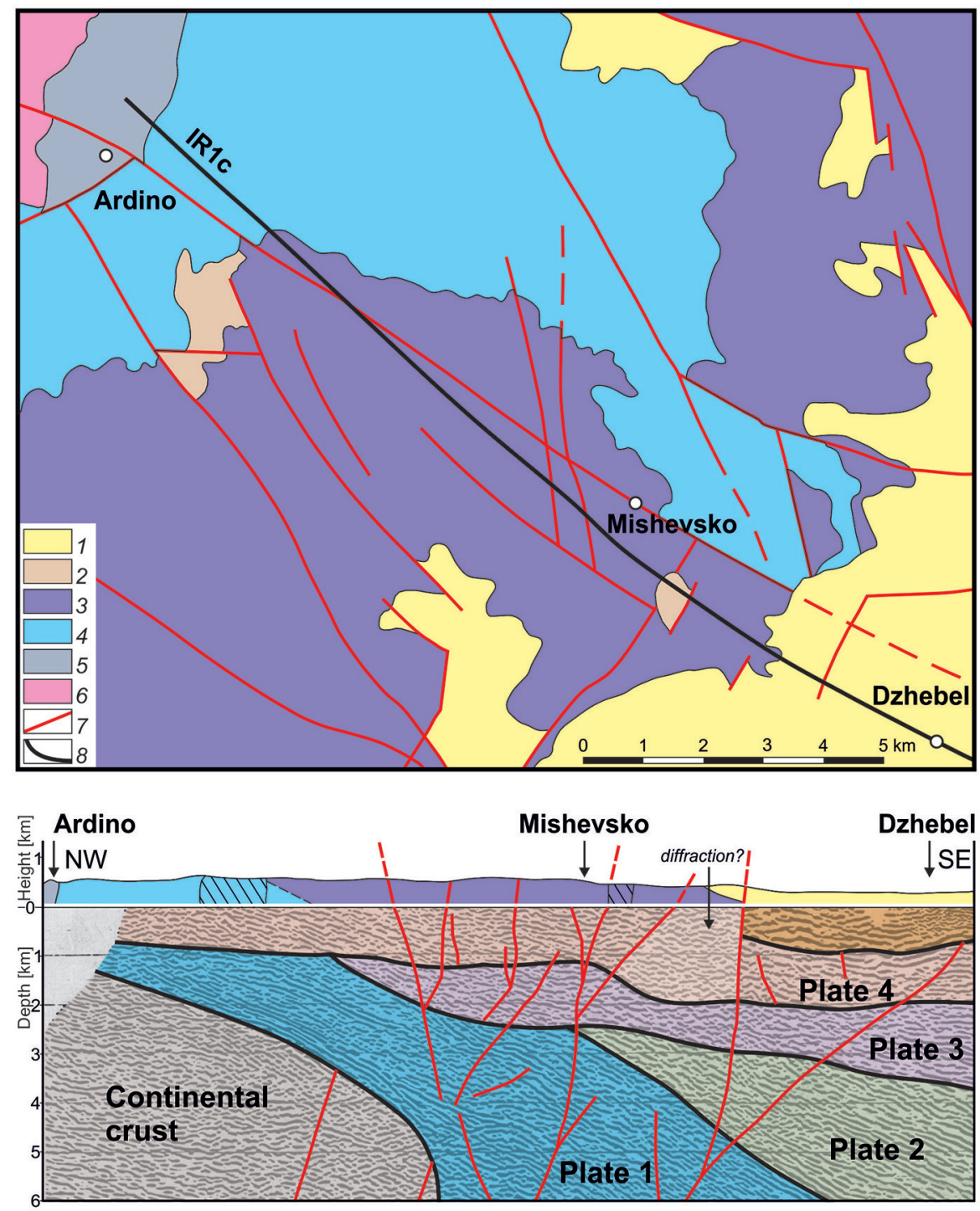

Fig. 5. Geological scheme (after Kozhoukharov et al., 1989) of the region of the western end of the seismic profile, segment IR 1c. Below is shown a part of its seismic record (after Fig. 2, no vertical exaggeration) with a geological section (above zero) presented on the relief that is cut off at the construction of the seismic profile. Legend: 1 - Paleogene sediments and volcanics; 2 - Rupelian rhyolite stocks in the crystalline basement (on the geological section, the projection of the rhyolite stocks cropping near the seismic profile is presented with hatching); 3 - Vacha Variegated Formation; 4 - Bogutevo Plagio-gneiss Formation; 5 - Chepelare Variegated Formation (Ardino “mélange”); 6 - Lyubino Granitogneiss-migmatite formation; 7 - important faults; 8 - line of the seismic profile, segment IR 1c. 
distribution of high-amplitude reflections, is not determined. The reflective sites, although predominantly sub-horizontal, are short and echelon-like situated. The seismic pattern indicates a complicated interior structure, as is actually recorded in the surface outcrops.

In conclusion, we can summarize that the four described plates have played a role in the buildup of the Eastern Rhodope Terrane, and at least two (1 and 2) of them build up the west-vergent obduction complex. In large or small areas between them, a sharp discordance is established. This discordance gives us a reason to admit that a separate phase of obduction corresponds to each seismic plate. Plate 3 could be included in the obducted complex, according to its present configuration and the relationships with Plate 2 and its concordant layering in the central part of the profile IR 1c.

Plate 4 abruptly differs in its position and configuration from the underlying obduction complex. It has traces of a later shear zone with an almost horizontal lower plane and a proven compression movement to the south marked by the sense of shearing (e.g., Burg et al., 1996), possibly remobilized with the top levels of the Plate 3 . So, the four plates of the Eastern Rhodope Terrane built up an obductionthrust complex.

The described plates are significantly different from the macro layers of Velev et al. (1995; 1996) and Velev (1996), which are also four, noted with alphabetic labels. Macro layer A is the upper one with thicknesses of $9 \mathrm{~km}$ to the west and $18 \mathrm{~km}$ to the east. This macro layer roughly coincides with our distinguished plates 2, 3 and 4 . The macro layer $\mathrm{B}$, located below, has a thickness of 3-4 km and includes part of Plate 1. Macro layer $C$ is the Lower crust. Macrolayer $\mathrm{D}$ is inclined, with a thickness of 3-6 km and to a depth of $20 \mathrm{~km}$ from the surface.

\section{LOWER CRUST-UPPER MANTLE}

The depth of the Mohorovichich Discontinuity in SE Bulgaria varies from $28 \mathrm{~km}$ to $36 \mathrm{~km}$ according to the geophysical data and interpretations without using any information from the discussed seismic profiles (Boykova, 1999). Along the IR 1c seismic profile, the depth is considered to be $30-32 \mathrm{~km}$ (Velev, 1996; Zdraveva et al., 1996). Reflections from the Mohorovichich Discontinuity on this seismic profile were also recently reported by Khrischev and Shanov (2017) and Khrischev et al. (2017). However, there is no clear change of the seismic record in both the Lower crust and Upper mantle, which makes their separation difficult. Taking into account the regional configuration of the
Mohorovichich Discontinuity and its appearance on the seismic wave-field plots as a band of double to triple reflection package across differently oriented reflectors, the discontinuity can be followed as a sequence of short linear segments along the seismic profile IR 1c (Fig. 2). The seismic section of the IR 1c profile shows a relatively clear reflection at these depths that we accept to belong to the Mohorovichich Discontinuity. It is traced more surely in the eastern part of profile IR 1c at a distance of about $25 \mathrm{~km}$ between the village of Zvezdel and the town of Krumovgrad.

The Mohorovichich Discontinuity is dipping westwards, underlying the continental crust at the western part of the seismic cross section. However, at the eastern part of the continental crust, the discontinuity is not clearly detectable. Eastwards, the boundary of the continental edge is not clearly marked in the Lower crust due to the very gradual transition from clearly sub-horizontally laminated to more transparent areas. Inside the continental crust, the reflections slightly twist upwards to the east and mark the contour of the continental edge (Fig. 2).

The space between the Mohorovichich Discontinuity and the base of Plate 1 in the sub-oceanic Eastern Rhodope Terrane is considered as a part of the Lower crust and here two different areas are distinguished (Fig. 2). The first one is characterized by a high degree of transparency and occupies the middle section of the profile (between the Varbitsa River and Krumovgrad Town). It is mushroom-shaped at the profile plane and climbs down to depths up to $18 \mathrm{~km}$. This is very similar to the magma-generating or magma-storage zone formed in the Lower crust (see section "Igneous bodies").

In the second area, the Lower crust has a clear stratification under one shear zone at depth of $24 \mathrm{~km}$ (assumed to be the lower boundary of Plate 1) in the eastern part of profile IR 1c. It is expressed by short, mostly sub-horizontal reflections at the upper part. Hence, we traced a boundary at depths of 24$25 \mathrm{~km}$, raising to depth of $22 \mathrm{~km}$ below Krumovgrad Town, and crossing the whole seismic section. This boundary marks the limit of penetration of most of the detected sub-vertical faults. Following Scholz (1988), this discontinuity is accepted as a boundary between the schizosphere and plastosphere. The lithosphere consists of two parts with markedly different rheological properties, one brittle and one ductile, respectively (Scholz, 2002). The schizosphere is the uppermost brittle part, and the plastosphere is the moldable, ductile part. Normally, the position of this boundary in the Earth's crust is controlled by the tectonic compression and the heat flow. If so, it is the undoubted lower boundary of Plate 1 . 
On profiles IR 1a and IR 1b, segments of seismic wave packages, most probably reflecting the Earth's crust/mantle boundary, are also identified (Figs 3, 4), as well as the boundary schizosphere/ plastosphere. Thus, the depth of the Mohorovichich Discontinuity varies between $27 \mathrm{~km}$ and $33 \mathrm{~km}$, dipping south-eastwards on cross-section of the seismic profile IR $1 \mathrm{~b}$ (Fig. 3), and from $31 \mathrm{~km}$ to $33 \mathrm{~km}$, dipping eastwards on cross-section of the seismic profile IR 1a (Fig. 4).

The boundary schizosphere/plastosphere is not well enough expressed. It is perturbed below the village of Konnitsi on profile IR 1b, the offset being of $1 \mathrm{~km}$ (depth from $21 \mathrm{~km}$ to $23 \mathrm{~km}$ ). On the seismic profile IR $1 \mathrm{a}$, the boundary is at a depth of $24 \mathrm{~km}$, also perturbed at its central part.

Inside the whole cross-sections of the Lower crust along these two profiles, very clear "crossed reflections" are present. These structures of the seismic wavefield are described here below the Kobilino Crypto-dome. They can also be seen inside the Upper mantle. This type of reflections is seen only in the Lower crust at the eastern end of profile IR 1c.

The seismic wavefield below the Mohorovichich Discontinuity on the cross-sections along the profiles IR 1a, IR 1b and IR 1c presents evidence of low- to wide-angle reflections. We are not discussing these structures of imposed and gradually inclined reflections in the deeper levels, which correspond to the Upper mantle, because they can be properly analyzed only if we know the parameters of the final processing of the data and avoid any doubts about their reality and the possibility of the existence of coherent noise (multiple reflections, diffraction) at the bottoms of the cross-sections.

The origin of reflective structures inside the Upper mantle is a matter of debate. In any case, similar structures are indicators of anomalous seismic velocities and densities. They are significantly increased if homogeneous zones are replaced by zones of inhomogeneous petrophysical properties resulting from constructive interference, as opined by Hansen and Balling (2004). Their statement is that "[a]pproximately maximum petrophysical contrasts may occur within relict subduction slabs containing a mixture of residual (oceanic or continental) crustal material of relatively low-density, low-velocity and high-density, high-velocity eclogite. If, for some reason (e.g., lack of sufficiently high temperatures or lack of fluids), a high degree of eclogitisation does not occur, such structures may have formed. Also, topography on the crust-mantle boundary, such as major Moho offsets and associated locally thickened lower crust (e.g., in areas where remnant subduction slabs dip into the mantle), significantly affects the wide-angle wavefields”.

In our case, accepting the consecutive obductions during the Paleozoic and/or Mesozoic (see section "Geodynamic hypotheses about the obduction age") and the subduction from Late Cretaseous time (Shanov et al., 1992), we can postulate that, probably, the reflections from structures in the Upper mantle are due to very complex accumulation of reprocessed crustal materials.

\section{GEOLOGICAL DATA ON THE EARTH'S CRUST AND THE UPPER MANTLE}

\section{Composition of the Upper mantle and Lower crust}

Limited data on the mantle's composition in the Eastern Rhodope Terrane are published. The spinellherzolite mantle xenoliths in the Chattian alkaline basalts and lamprophyres from the Krumovgrad region and the geochemical characteristic of the hosted rocks determined the initial mantle as "garnetbearing LREE-enriched peridotite mantle source containing metasomatic biotite" (Marchev et al., 1998, 2004a). These rocks also contain olivine websterites, ortho- and clinopyroxenites, and gabbros representing cumulate xenoliths of layered plutons (Marchev et al., 2006a). Thermobarometric studies suggest their formation at a depth of 30-45 km (Upper mantle/Lower crust).

Yanev and Ivanova (2008/2009, and references therein), on the basis of $\mathrm{Dy} / \mathrm{Yb}$ ratio in the Rupelian trachydolerites from Planinets Village (crossed by profile IR 1a), south of Popsko Village, assumed its amphibole- and/or phlogopite-containing garnetlherzolite mantle source.

\section{Composition of the Rila-Western Rhodope Terrane}

The western end of the seismic profile IR 1c falls on the eastern part of the CRD or Arda Dome with continental Earth's crust. The dome is built of highgrade metamorphic rocks referred, according to the lithostratigraphic subdivision, to the Pre-Rhodopean Supergroup (Lyubino and Vishnevo formations) (Kozhoukharov et al., 1989). According to this subdivision, the rocks of this supergroup build up also the core of the Byala Reka and Kesebir-Kardamos domes in the Eastern Rhodopes. According to the lithotectonic division of the Rhodope Metamorphic Complex, these rocks are a member of the Arda Lithotectonic Unit of Ivanov (2000) or Lower Allochthon of Dinter and Royden (1993) These rocks, 
mainly orthogneisses (derived from CarboniferousUpper Jurassic granitoids - Ovtcharova et al., 2002; Peytcheva et al., 2004), are metamorphosed in the amphibolite facies with intensive processes of migmatization. The age of the latest melting-metamorphic process is dated at $37.8 \pm 1.5 \mathrm{Ma}$ (Cherneva et al., 2002) and $38 \mathrm{Ma}$ (Peycheva et al., 2004).

\section{Composition of the Eastern Rhodope Terrane}

It comprises the four seismic plates built up by subocean Earth's crust with allochthon meta-granite packets.

\section{Plate 1}

There are no data on the rock composition and age of the plate due to the fact that they do not have outcrops on the surface, but their topmost part is very close to the surface western of the town of Ardino (Fig. 5). Through extrapolation, we suggest that herein, in the frame and western of the StartsevoArdino Shear Zone, the outcrops of the Ardino "melange" (Fig. 1) and layers of meta-basites in the area of Galabovo Village (northwest of Ardino) represent the deeply exported slices of the Plates 1 . The outcrops are represented by ortho-amphibolites, meta-gabbro and eclogite lenses, and bodies of meta-ophiolites. According to the lithostratigraphic division of the high-grade metamorphic rocks in the Rhodopes, these rocks are referred to the Vishnevo and Luybino formations of the Pre-Rhodopean Supergroup (Kozhoukharov, 1988) and the Chepelare Variegated Formation of the Rhodopean Supergroup or an element of the Startsevo Lithotectonic Unit (Sarov et al., 2004). The published data for some of these meta-basites show its sub-oceanic characteristics (Pristavova, 1995; Pristavova and Daieva, 1998; Daieva et al., 2007; Kirchenbaur et al., 2012b) with metamorphic condition of eclogite facies $700-800{ }^{\circ} \mathrm{C}, 14 \mathrm{kbar}$ (e.g., Kolcheva et al., 1986; Pristavova, 1995) and amphibolite facies 550-720 ${ }^{\circ} \mathrm{C}$, 7-9 kbar for various metamorphic rocks (Pristavova, 1995; Ovtcharova, 2005). The data for the protholith age are still missing and only published $\mathrm{Lu} / \mathrm{Hf}$ isotope ratio in garnet suggests 45-42 Ma as probable age of the eclogite metamorphism (Kirchenbaur et al., 2012b).

\section{Plates 1 and 2}

We could also presume that other deeply exported slices from Plates 1 or 2 are probable meta-ophiolites like serpentinized dunite-harzburgite massifs as Dobromirtsi, Golyamo Kamenyane-Yakovitsa and Gledka. They could have been elevated by the Dobromirtsi Fault Bundle (Popov et al., 1972) or Xanthi Fault (Ivanov, 2017), reaching the plane of the obduction zone. All these rock fragments show geochemical features from the transition continentocean zone and only the Yakovitsa Massif has typical oceanic geochemistry (Bazylev et al., 1999, and references therein). With regard to the age of the ultramafic protolith of some of these ophiolite bodies, as the Dobromirtsi ophiolite, there is a suggestion that it is an old mantle derivate and it was reworked in the Paleo-Proterozoic and possibly even younger times (González-Jiménez et al., 2015).

Some sporadic xenoliths in the Paleogene volcanic rocks are found (plagioclasite, clinopyroxene granulite and clinopyroxenite) in the basaltic andesite to shoshonite west of Krumovgrad Town (Nedialkov, 2010), which can be characterized as inclusions probably from Plate 2, in which the magma chambers are located, but their age has not been determined yet.

\section{Plate 3}

It is exposed at the eastern end of the seismic profile IR 1c (east of the Avren Fault - Fig. 6) and along the IR $1 \mathrm{~b}$ and IR 1a profiles. This plate is made up of gneisses (meta-granites), biotite gneisses, gneissschists, two mica schists, amphibolites, marble, and meta-ophiolitic fragments. Stratigraphically, these rocks are referred to the two supergroups: (i) the lower part to the Pre-Rhodopean Supergroup (Boturche and Arda groups, the last consisting of the Belo Pole gneiss and the Tintyava Granitegneiss formations); (ii) Rhodopean Supergroup (the upper part with a varied composition of the Jailadzhi Member of the Chepelare Formation). According to the lithotectonic division (Sarov, 2012), this part of Plate 3 refers to the Byala Reka Lithotectonic Unit, corresponding to the Lower Allochthon (Burg et al., 1996). It is built up of meta-granites (regulargrained and porphyry) with single lens-like bodies of garnet-containing mica schists and biotite gneisses, the middle part with meta-ophiolitic fragments, and the upper part with biotite schists, gneiss-schists, amphibolites, and marbles. The rock composition of this plate shows mixed genesis - continental for the meta-granites, which are allochthonous bodies among the complicated metamorphic complex built up by the obducted ocean and sub-oceanic fragments (Kozhoukharova, 1984). For all metamorphic rocks included in the frame of Plate 3, green-schist to lowtemperature amphibolite facies of metamorphism is a characteristic feature. The P-T conditions of 430 $470{ }^{\circ} \mathrm{C}$ and 5-8 kbar for meta-granites are obtained (Macheva and Kolcheva, 1992). The polyphase 
metamorphism is distinguished in the gneiss-schists and for the meta-granites at $13 \mathrm{kbar}$ and $\sim 450{ }^{\circ} \mathrm{C}$ (first phase); 3-9 kbar at $\sim 500{ }^{\circ} \mathrm{C}$ (second phase); and 2-3 kbar at $400{ }^{\circ} \mathrm{C}$ (last phase). The obtained age of the granite protholith is in the frame of 305310 Ma (Peytcheva and von Quadt, 1995), as well as reaching up to $301 \pm 4 \mathrm{Ma}$ (Carigan et al., 2003). For the meta-eclogites with a mantle-derived source from the same unit, Devonian age (380.4 $\pm 2.2 \mathrm{Ma})$ of the protolith is documented (Macheva et al., 2018).

The seismic profile IR 1a (west of Ivayovgrad Town) crosses the outcrops of the Triassic-Jurassic (greenschist facies) rocks of the Mandritsa Lithotectonic Unit (after Sarov et al., 2008) or Low-grade Mesozoic Unit (after Bonev et al., 2010b), corresponding to the Uppermost Allochthon. In the volume of this unit, the low-grade metamorphic rocks and their diaphtorized basement are included (Fig. 1). The seismic reflectance does not allow us to distinguish them from the seismic pattern of Plate 3.

\section{Plate 4}

This plate is exposed on the surface at the western end of the IR 1c profile between Ardino Town and Mishevsko Village (Fig. 5), and a small part in its end, west from the Avren Fault (Fig. 6). In the two outcrops, this plate consists of plagiogneisses (biotite-amphibole) and fine-crystalline biotite gneisses, gneiss-schists and schists, amphibolite, eclogite, marbles, and meta-ophiolitic fragments. According to the lithostratigraphic division, the two outcrops of Plate 4 are referred to the Bogutevo Plagio-gneiss Formation and the Vacha Variegated Formation of the Rhodopean Supergroup. The same lithological varieties in the western part of the profile IR 1c are referred to the Startsevo Lithotectonic Unit (Middle Allochthon) and to the Krumovitsa Unit (Upper Allochthon) in the eastern part. These units are not distinguishable one from another according to their reflective seismic pattern in this part of the seismic profile IR 1c. The rocks from both units have sub-oceanic and oceanic genetic characteristics, with evidence of high-grade regional metamorphism in the frame of eclogite and amphibolite facies (680-780 ${ }^{\circ} \mathrm{C}, 5-12$ kbar, Haydoutov, 2004). The rocks here are with a high degree of metamorphism exceeding that of the underlying Plate 3. The published data about the age of the protolith and metamorphic events are numerous and they could be resumed as follows: (i) for most of the oceanic and sub-oceanic products (metagabbros and garnet amphibolites) from both lithotectonic units (within the Vacha Variegated Formation), the protolithe age data are within the limits of $470 \mathrm{Ma}$ to $430 \mathrm{Ma}$ (Ovcharova, 2005; Bonev et al., 2010a; Bonev, 2015), 566.4 $\pm 6.3 \mathrm{Ma}$ (von Quadt et al., 2010), and for meta-plagiogranites $-511 \pm 5 \mathrm{Ma}$ with variation centre-periphery $468 \pm 8 \mathrm{Ma}$ and 442 \pm 4 Ma (Bonev, 2015); (ii) for metamorphic events in different rocks that are elements of Plate 4: high-pressure metamorphic event in meta-pelites 155 Ma (Georgieva, 2014), in eclogites - 126 Ma (Kirchenbaur et al., 2012b) and $73 \mathrm{Ma}$ (von Quadt et al., 2010), and amphibolite facies - in meta-pelites 73 Ма (Georgieva, 2014), in meta-gabbros - 4947 Ma (Bonev et al., 2010a).

\section{Paleogene cover}

The Eastern Rhodope Paleogene Depression is located entirely on the sub-oceanic crust, characterized by a high gravity field (Fig. 1). Its rocks lie discordantly mainly on Plate 4 (Fig. 7). The seismic profile IR 1c crosses parts of the southern portion of the depression (two of its components) - secondary-order Dzhebel and Krumovgrad depressions, which are separated by the Zvezdel Horst (northern extension of the Ribinovo Elevation of Boyanov and Goranov, 2001). The sediments dip at a low angle in both depressions and only in the periphery of the basins and on the volcano slopes more significant inclinations can be found. The profile IR 1a (Fig. 4) enters in the western periphery of the Eastern Thracian Depression in the region of Ivaylovgrad Town (secondary-order Mandritsa Depression after Boyanov and Goranov, 2001). Its sediments lie almost concordantly on Plate 3.

\section{Dzhebel Depression}

The Dzhebel Depression (Fig. 7) is bordered by faults: the western one belongs to the Dobromirtsi Fault Bundle (Popov et al., 1972), probably longlived, predicts the high amplitude of displacement (Fig. 5); the eastern slope is stepped, formed by reverse-slip faults. The depth of the depression is $1.0 \mathrm{~km}$ and $1.2 \mathrm{~km}(+0.3 \mathrm{~km}$ "cut off" from the relief by the construction of the seismic profile), respectively below the town of Dzhebel and the Varbitsa River. Rupelian rocks crop out in the depression: sediments ("Dzhebel sandstones"), epi- and pyroclastics, intersected by andesites (the western periphery of the Zvezdel volcano) and rhyolites (Ustra domecluster), as well as rhyolite dykes and sub-volcanic stocks forming a linear swarm with ESE direction (Galenite swarm). The Priabonian and older Paleogene sediments crop out only in the southernmost part of the depression (in Podkova region).

The seismic data permit to resolve the question of the absence (according to Atanasov et al., 1972; 

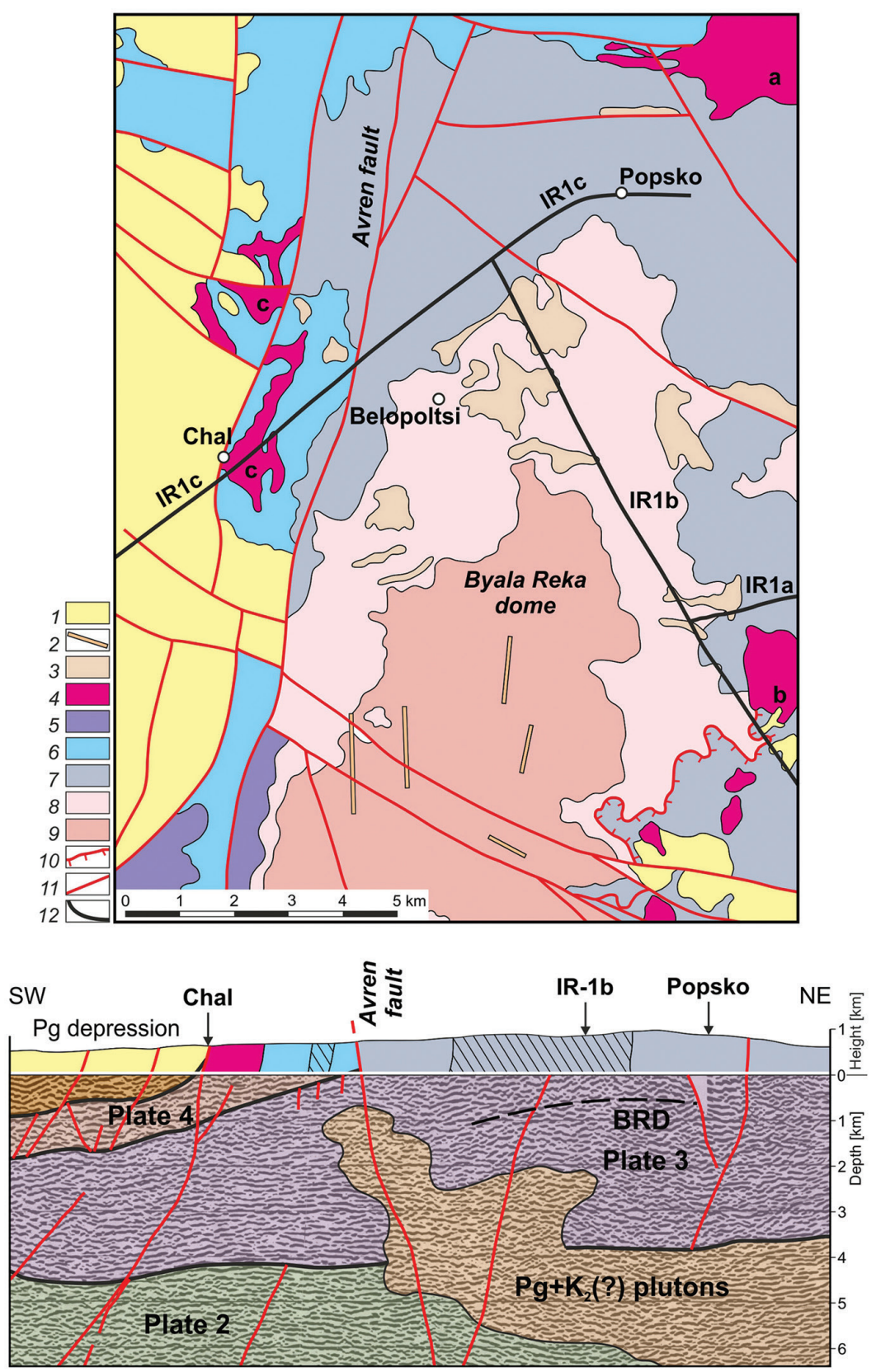

Fig. 6. Geological scheme (after Kozhoukharov et al., 1992) of the region of the seismic profile, segment IR 1b and the eastern end of segment IR 1c. Below is shown a part of the seismic records of segment IR 1c (after Fig. 2, no vertical exaggeration) with a geological section (above zero) presented on the relief that is cut off at the construction of the seismic profile. Legend: 1 - Paleogene sediments and volcanics; 2 - Rupelian rhyolite dykes; 3 - Rupelian rhyolite stocks (on the geological section, the projection of the rhyolite stocks cropping near the seismic profile is presented with hatching); 4 - Upper Cretaceous granitic plutons: dated (a - Chuchuliga, b - Rozino) and supposed (c - Chal-Disevitsa); 5 - Vacha Variegated Formation; 6 - Bogutevo Plagio-gneiss Formation; 7 - Chepelare Variegated Formation; 8 - Belo Pole Gneiss Formation; 9 - Tintyava Granite-gneiss Formation; 10 thrust; 11 -important faults; 12 - line of the seismic profile. BRD - Byala Reka Dome.

Boyanov and Goranov, 2001; Georgiev, 2002) or the presence (according to Popov et al., 1972) of Priabonian sediments below the Rupelian ones in the whole depression: the thickness of the sediments is $1.2 \mathrm{~km}$ according to the seismic profile in the val- ley of the Varbitsa River (at Ptichar Village) and the thickness of the Rupelian section is $\sim 100 \mathrm{~m}$ only (Velev and Yanev, 1966). Therefore, it can be assumed that the Priabonian (and possibly older) sediments there have a thickness not less than $1 \mathrm{~km}$. 


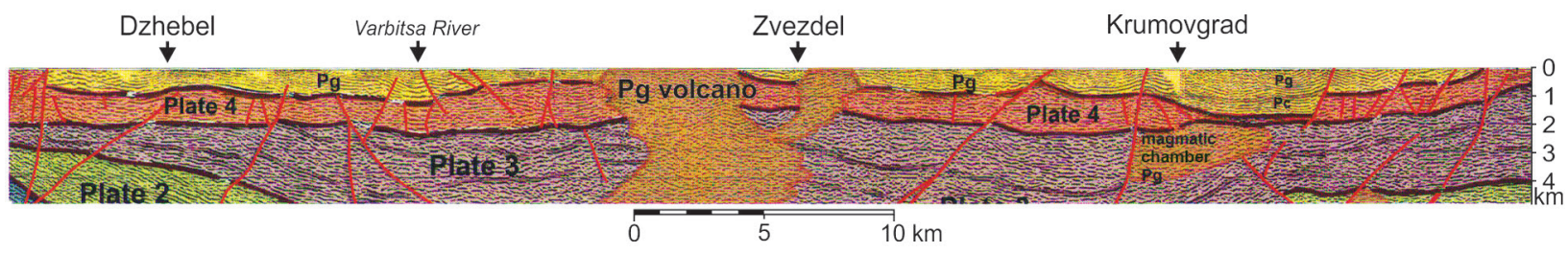

Fig. 7. Part of segment IR 1c of the deep seismic profile (after Fig. 2) crossing the Paleogene cover - Dzhebel and Krumovgrad secondary-order depressions separated by the Zvezdel Horst (with magmatic chamber of the Rupelian Zvezdel volcano). Pc - probable Upper Cretaceous-Paleocene (?) sediments of the Shavara and Kandila formations.

\section{Zvezdel Horst}

The uppermost part of the Rupelian section crops out only here and the metamorphic basement (Plate 4) is revealed in the southern end of the horst.

\section{Krumovgrad Depression}

The Krumovgrad Depression (Fig. 7) has gently inclined western slope and a stepped elevated eastern one due to reverse-slip faults. The depression is filled by the Maastrichtian-Paleocene (?) sediments of the Shavar and Kandila formations (Goranov and Atanasov, 1992), Priabonian and Rupelian sediments, acid tuffs, andesites to latites and their epiclastites. The seismic record outlines wellvisible layers in the lower part of the cross-section (probably Priabonian sediments) and intermittent, frequently wedging layers - in the upper part of the section (probably Rupelian pyroclastic and volcano-sedimentary rocks).

The Paleogene sediments have the largest thickness east of Krumovgrad Town $(1.2 \mathrm{~km}+0.4 \mathrm{~km})$, where a package with high reflectance and thickness of $0.6-0.7 \mathrm{~km}$ is distinguished under them. This package is incised into Plate 4, reaching Plate 3 . We interpret this package as sediments of the Shavar and Kandila formations, consisting of breccia with olistoplaques of gneisses and marbles, as well as sandstones, limestones and marls (Goranov and Atanasov, 1992).

\section{Eastern Thracian Depression}

The Eastern Thracian Depression (Fig. 4) has a gently inclined slope and a maximal thickness of $1.5 \mathrm{~km}$ $(+0.2 \mathrm{~km})$ on the Bulgarian territory. The seismic profile separates two packets. The lower one has a well-visible layering, probably related to the Priabonian and Rupelian sediments and acid pyroclastic rocks cropping out near the periphery of the depression. The upper one is thicker, almost transparent package. It corresponds to a fluvial-lake formation of conglomerates, sandstones, siltstones and clays with presumed early Miocene age (Boyanov and Goranov, 2001).

\section{Igneous bodies}

\section{Upper Cretaceous and Tertiary (?) plutons}

The seismically transparent and homogeneous areas stand out among the well-layered rocks of all plates in the three studied seismic profiles (Figs 2-4). We interpret these areas as plutons, possibly with Late Cretaceous and Tertiary (?) age, similar to those revealed on the surface in the eastern end of the profile IR 1c (Fig. 6), e.g., Chuchuliga (68.84 $\pm 0.40 \mathrm{Ma}$ ) and Rosino (68 $\pm 15 \mathrm{Ma}$ - Marchev et al., 2006b). They are I-type granites (Stoykov and Mavrudchiev, 1997), most often two-mica or muscovite-containing, considered to be products of fractionation of mantle generation magma. Another pluton with intermediate composition and $\mathrm{Au}-\mathrm{Pb}-\mathrm{Zn}$ mineralization is found by boreholes in the area of Popsko Village (Mavrudchiev, 1992).

Two supposed plutons appear in the profile IR 1a below $15 \mathrm{~km}$ (Fig. 4), cutting the eastern slope of the Kobilino Crypto-dome that marks the older age of the dome. Other transparent areas, also interpreted as small plutons inclined to the west, are located at a depth of $2 \mathrm{~km}$ below Krumovgrad (Fig. 2) and the Adatepe gold deposit. This fact raises questions about the supposed amagmatic origin (Marchev et al., 2004b) of the ore deposit.

\section{Paleogene magmatic bodies}

On the seismic profile IR 1c, an area with transparent diffraction pattern (sizes $14 \times 11 \mathrm{~km}$ ), especially in Plates 2 and 3, is distinguished below the Rupelian Zvezdel volcano (Fig. 2). We interpret this area as a magma chamber of the volcano including the entire halo of contact-fluid alteration in the hosted metamorphic rocks. The volcano, with a diameter of more than $16 \mathrm{~km}$, is built up of basalt and basaltic andesite (Yanev et al., 1989) to dacite with a predominance of andesite (Raicheva, 2013) with their 
pyro- and epiclastic rocks. There is also a small pluton with a differentiated composition, from gabbro to granosyenite with a predominance of monzonite (Nedialkov and Mavroudchiev, 1995). Raicheva (2013) determined the crystallization depth of the volcanic phenocrysts at $10-13 \mathrm{~km}$ using various geobarometers, which corresponds to the lower part of the magma chamber in Plate 2 according to the seismic data. Only for some amphibole crystals, the determined depth is $17-20 \mathrm{~km}$, which probably came from deeper levels of magma generation in the Lower crust (see below).

The seismic profile IR 1c intersects other Rupelian volcanic bodies: small rhyolite domes and dykes near Ardino Town and Mishevsko Village on the eastern slope of CRD (Fig. 5), as well as those in the region south of Popsko Village on the northern end of the Byala Reka Dome (Fig. 6). The magma chamber in the first area must have been too small to reflect on the seismic record. In the region of Popsko Village, on the contrary, there is a seismicly transparent area, inclined to the east at a depth from $0.5 \mathrm{~km}$ to $8.5 \mathrm{~km}$. We interpret this area as a possible residue of an acid magmatic chamber, which produced the Rupelian rhyolites in the region. However, it could include older, Upper Cretaceous, granites such as the small stocks that crop out in the area of Disevitsa and Chal villages just above the highest western part of this body.

\section{Mushroom-shaped body}

A seismicly transparent area (length $19 \mathrm{~km}$ and thickness between $13 \mathrm{~km}$ and $8 \mathrm{~km}$ ) at a depth of $20 \mathrm{~km}$ to $18 \mathrm{~km}$ in the Lower crust and the bottom of Plate 1 is observed on the IR 1c profile between the Varbitsa River and Krumovgrad (Fig. 2). We interpret it as a probable a heated part of the Lower crust and Plate 1 and suggest that:

(i) the "softening" of the Lower crust and the creation of this mushroom-shaped body caused the collapse of the obduction-thrust complex. This led to the formation of the Dzhebel-Krumovgrad Upper Eocene-Oligocene depressions, having an ellipsoidal shape of $\sim 32 \times 20 \mathrm{~km}$ dimension, while earlier Maastrichtian-Paleocene sediments "accumulated in supradetachment half-grabens" associated with the exhumation of the KesebirKardamos and the Byala Reka domes (Bonev, 2006). Radially oriented grabens with Paleogene sediments, located within the framework of the Dzhebel-Krumovgrad depressions, emphasize its collapse character.

(ii) the mushroom-shaped body had a generating role for the Paleogene magmatism. The seis- mic profile shows that the magmatic chamber of the andesite Zvezdel volcano is situated just above this body, marked by a negative gravity anomaly (Fig. 1) against the positive gravimetric field of the whole Eastern Rhodope Terrane. Because the seismic profile cuts the southern periphery of the Dzhebel-Krumovgrad depressions, it can be assumed that the mushroom-shaped body will be larger in size and with a greater thickness towards the centre of the depression (north of Zvezdel Village), probably affecting the Upper mantle as well. This would lead to the formation of more basic magma chambers. Maybe, it concerns the latite Sveti Iliya volcano and andesite Irantepe volcano (Fig. 1), which are marked by positive gravity anomalies.

\section{TECTONIC STRUCTURES}

\section{Obduction surface and seismic plate boundaries}

The obduction surface is an S-shaped line with a steep area in the middle part at a depth of $5 \mathrm{~km}$ to $8 \mathrm{~km}$ (Fig. 2). Narrow diffractive bands are distinguished on the two sides of this surface, a probable effect from the frontal pressure deformations. In the inclined sectors, the layering is retained in the very lower part of Plate 1, which is a possible indication of the free shear movement in the brittle-plastic environment.

The boundaries between the lower three seismic plates are well-defined shear zones with a particularly pronounced discordance between Plates 1 and 2. This discordance seals the effects of tectonic events followed by a series of interlayered and inclined shear zones in Plate 1 . The lower boundary of Plate 4 is presented also by a thrust sub-horizontal zone with movement to the south marking clear discordance to the lower plates.

\section{Metamorphic core complexes (MCC)}

The structure of the metamorphic basement and one "blind" structure in depths named Kobilino Cryptodome, which are crossed by seismic profiles, are described.

\section{Central Rhodope Dome (CRD)}

The eastern periphery of this dome, represented by the Madan-Davidkovo Dome, is crossed by the western end of profile IR 1c and its boundary is traced by the obduction surface. The reflectance pattern supports the idea of its nature as an exhumated metamorphic core complex (Ivanov, 2000). 


\section{Byala Reka Dome (BRD)}

It is presented by outcrops of gneisses and granitegneisses from the Pre-Rhodopean Supergroup and variegated Chepelare Formation of the Rhodopean Supergroup or the Byala Reka Lthotectonic Unit. In the profile IR 1c, the central part (in the area of Popsko Village) is marked by weakly folded reflections in Plate 3 (Fig. 6). The Avren Fault crosses the western board of the BRD.

\section{Kobilino Crypto-dome}

It is established according to the data of the seismic profile IR 1a (Fig. 4). The crypto-dome is built up mainly by the rocks of Plate 1 and the upper part of the mantle; it has a height of 23-26 km and a horizontal dimension of over $20 \mathrm{~km}$. It is clearly outlined on the finely-layered rocks from its slopes, having an inclination of $20^{\circ}$ at the base and up to $40^{\circ}$ on the slopes, which is unusual for the dome. The upper part of the crypto-dome is quite transparent, without clear reflective planes. In its arch, the upper Plate 2 has a reduced thickness of up to $1.5 \mathrm{~km}$. This plate lies with conformity in the eastern slope and with disconformity in the western one with an increased thickness of up to $7 \mathrm{~km}$. The structure is covered by Plate 3, whose base copied the top of the dome. We interpret this structure, composed of mantle rocks, Plates 1 and 2, and covered by Plate 3, as an old metamorphic core complex (MCC).

At a depth from $20 \mathrm{~km}$ to $30 \mathrm{~km}$, in the core of the crypto-dome, there is an area with crossed seismic reflections. This area occupies the plastopshere and the top part of the Upper mantle. It is also tracking on an IR 1b profile (Fig. 3) crossing the western periphery of the dome. Such a seismic picture is observed at the base of some MCC (e.g., in the California coast - ten Brink et al., 2000), in metamorphic terranes (e.g., in the Osaka region, Japan - Itoh et al., 2017), and it is particularly clear in the plastic rocks of the salt domes (e.g., Hegazy and AlRegib, 2014; Jones and Davison, 2014). The Mohorovichich Discontinuity below this area is not traced at some places. Therefore, due to the presence of "cross" reflections in the topmost part of the mantle, the Kobilino Crypto-dome can be referred to the mantle core complex according to the classification of Brun et al. (2018). We suppose that the "cross" reflections are formed in the deep, plastic part of MCC during the "growth" of the dome.

\section{Fault and shear-zone systems}

Five fault systems can be distinguished depending on the position in the cross-sections and the time of occurrence (Fig. 8). Some of the faults have low vertical amplitude, so they do not disturb the reflective boundaries at the scale of the seismic profiles. Their presence is registered by fractures of the reflection sites and diffraction.

System 1. It is represented by sub-horizontal shear zones in the continental crust of the CRD.

System 2. It is represented by a bundle of subvertical to westward-dipping faults in the area of obduction, i.e., in both continental and sub-oceanic crusts. Two sub-groups are distinguished in this system according to the time of activity: before obduction (2a) and after obduction, but before Paleogene sedimentation (2b), with re-activation after formation of sediments. Two of the faults are visible in the Lower crust at a depth of about $30 \mathrm{~km}$. Two faults of the 2b sub-group correspond to the Dobromirtsi Fault Bundle described as the pre-Paleogene structure (Popov et al., 1972) or the Xanthi Fault (after Ivanov, 2017), supported by other geophysical data (Yossifov et al., 1980).

System 3. These are two groups of well-expressed high-amplitude faults registered in the central part of profile IR 1c that tear Plate 1 and truncate some parts of this plate. The lower surface of Plate 2 is cut by this system. Some of the faults seem to have a continuation in higher levels of the profile but are not well expressed. The seismic pattern marks two stages of development of some of these structures. The first, and main one, marks the tearing and displacement of Plate 1 prior to the obduction of Plate 2. It is probably due to deep processes in the Lower crust and Upper mantle. The second possible stage is the reactivation of the faults in a new (Late Alpine?) period and the development of the Paleogene magmatism.

System 4 . This system probably incorporates the intra-plate shear zones in a brittle-plastic environment during the process of obduction. The most expressed are in Plate 1, where they are represented by sub-horizontal and sloping faults with a significant spatial distribution.

System 5. This system includes the youngest sub-vertical to inclined faults, most of them inclined to the Zvezdel Horst. They mark the extension stage of the Late Alpine evolution often crossing the whole profile and Paleogene cover. They are expressed on the surface as normal-slip and reverseslip faults (e.g., Avren Fault). These faults stop at a depth of 13-17 km, reaching the obducted oceanic crust (i.e., the lower boundary of Plate 1) with one exception: in the westernmost part of the studied region (profile IR 1a - Fig. 4). Herein, they penetrate at a depth of up to $30-32 \mathrm{~km}$ and come down to the Mohorovichich Discontinuity. 


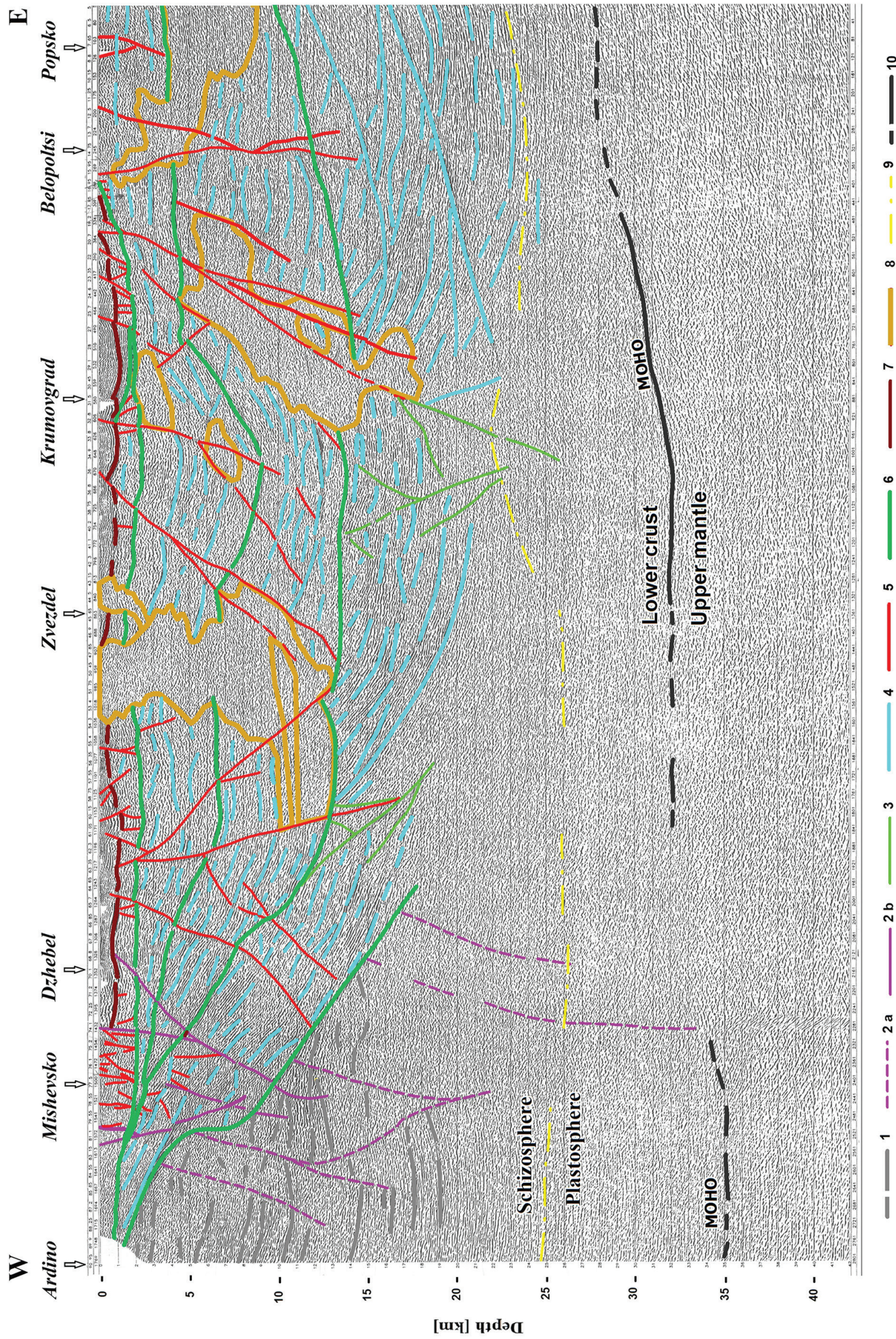


Fig. 8. Faults and shear-zone systems on the deep seismic profile (segment IR 1c). Legend: 1 - sub-horizontal shear zones in the continental crust; 2 - sub-vertical to westwards-dipping faults in the obduction area (2a - before obduction; $2 \mathrm{~b}$ - after obduction and before Paleogene sedimentation); 3 - high-amplitude faults impacting Plates 1 and 2 in the central part of the seismic profile; 4 - intra-plate shear zones; 5 - youngest sub-vertical to inclined faults; 6 - plate boundaries; 7 - base of Paleogene cover; 8 plutons and Paleogene magmatic chambers; 9 -schizosphere/plastosphere boundary in the Lower crust (following Scholtz, 1988); 10 - Mohorovichich Discontinuity (MOHO). Note: no vertical exaggeration.

\section{DISCUSSION}

\section{Geodynamic evolution of the Eastern Rhodope Terrane}

The concept of the Rhodopes as an obduction-thrust complex that is a result of compression and extension stages emanates from the obtained data from the seismic profiling. Here, we discuss the seismic picture result of the compression stages, mainly because the Late Alpine extension stage is widely studied in the geological literature (e.g., Burg, 2011; Zagorchev, 2015; Ivanov, 2017).

\section{Compression stages}

The two elements of the complex, obduction-related and subsequently thrust-related with the perpendicular direction of movement (sub-equatorial to the west and meridian to the south respectively), are formed as a result of compression. The obduction puts the two terranes in contact - the Rila-Western Rhodope (continental periphery) and the Eastern Rhodope (sub-oceanic). The boundary of these terranes is accepted to be the area situated in the west of Ardino Town including the Ardino-Startsevo Zone.

The four plates that build up the Eastern Rhodope Terrane, or at least two of them (1 and 2), are included in the west-vergent obduction complex. A sharp discordance is established in a large area or in the small areas between them. Plate 3 can be conditionally included in the obduction-related complex, according to the relationships with Plate 2 and also the concordant layering in the central part of profile IR 1c. Characteristic features of Plate 3 are the configuration of the seismic patterns and the heterogeneous structure observed, which is enriched by the metagranites. Plate 4 , in the western end of the same profile, covers with a horizontal boundary the highest levels of all three plates of the obduction-related complex, forming a south-vergent thrust (e.g., Burg et al., 1996; Bonev et al., 2010b, 2013a). The age of this thrusting is assumed to be in the beginning of the Late Cretaceous (Bonev et al., 2013a, 2015). The thrust's genesis should be found in the area of the Maritsa Zone, which is highly tectonized so that it produces divergent thrusts with opposite directions of the tectonic movement - in the Rhodopes verging to the south, and in the Srednogorie to the north (Bonchev, 1946, 1964; Ivanov et al., 1979). The north-vergent, but older (probably late Kimmeridgian - Bonev et al., 2010c, 2019), thrusts of the Triassic-Jurassic low-metamorphic rocks forming the Mandritsa Lithotectonic Unit should also be included in this thrust-related complex. It is believed that they originated from the Vardar Ocean.

\section{Extensional stages}

The only marks of the latest Late Alpine extension stage are traced on the seismic records. It is connected to the Tertiary exhumation of the Cenrtal (Arda) and Eastern (the Kessebir-Kardamos and the Byala Reka) Rhodope domes, the formation of the Tertiary depressions, the Paleogene magmatic activities (see below) and the network of sub-vertical and inclined faults. The biggest part of the last ones is old, having been renewed many times even after the deposition of the youngest Tertiary sediments.

The detachment fault of the exhumation of the CRD (Ivanov, 2000, pers. comm.) accommodates the obduction surface in the Late Alpine time. On the seismic profile, this movement is marked by lowering of the reflections in the uplifted side of the fault at a depth of 8-12 km (Fig. 8).

\section{Geodynamic hypotheses about the obduction age}

Two geodynamic hypotheses about the possible time of the obduction of the sub-oceanic Eastern Rhodope Terrane on the continental Rila-Western Rhodope Terrane could be suggested on the basis of the existing palinspastic reconstructions of the evolution of the Tethys (Stampfli et al., 2002; Stampfli 
and Hochard, 2009). It is also possible that these two hypotheses reflect two stages of obduction.

The first hypothesis is based on the participation of the Rhodopes during the Early Paleozoic in the peri-Gondwanan Hunic Superterrane (Bonev et al., 2013b). According to the model of Stampfli et al. (2002) this superterrane moved to the NE during the Late Devonian-earliest Carboniferous due to the extension of the Paleo-Tethys, and it accreted to the passive margin of Laurussia through the south-westward subduction of the Rheno-Hercinian and Paphlagonian oceans. At that time, but before the Visean, an intra-terrane transcurrent fault was formed, with E-W direction. Many terranes of its southern sector were displaced to the far west and those of the northern sector - to the east. The last ones probably closed the remnants of the Paphlagonian Ocean. So, this could be assumed to have resulted in the west-vergent obduction of the Eastern Rhodope over the Rila-Western Rhodope Terrane. Probably, the Eastern Rhodope Terrane had larger dimensions to the north, from where, during the Cretaceous (?), through the intra-terrane thrusting materials of proven Gondwanian protoliths, was included into Plate 4 (Bonev et al., 2013b).

With the Mesozoic development of the NeoTethys (Stampfli and Hochard, 2009) and especially with the evolution of the Küre back-arc Ocean can be related to another hypothesis. The Küre is reconstructed on the place of the present-day Black Sea with an unclear west boundary. This basin started to close by the subduction of the Sakarya Plate to the north and west during the Late Triassic and the Early Jurassic. These movements could also cause the described obduction. Thus, the idea of Gochev (1982) about obduction of the Eastern Rhodopes as part of the Strandzhidi over the Central Rhodopes can be revived. This collision leads to the Late Jurassic orogenesis (Bonev et al., 2010b). The granitization from the latest Jurassic-earliest Cretaceous orogenesis in the Central Rhodopes (144 Ma - Cherneva et al., 2014, and others) could be related to this process. Zagorchev et al. (2015) named this as the "Late Kimmeridgian (Jurassic) channel flow and hot orogeny channel” and Gautier et al. (2017) the first anatexis during Alpine time.

\section{Relationships of the Paleogene volcanism with the Earth's crust structure}

The first interpretations of the deep geophysical data underlined the influence of the nature of the Rhodope Earth's crust on the formation of various Paleogene magmas (Velchev et al., 1971). In this paper, it has been pointed out that, in the thin crust of the East Rhodopes, characterized by "reduced thickness of the granite layer and a high density of basic and ultrabasic bodies" magmas with the intermediate composition are formed, while in the thick crust of the Central Rhodopes with very thick granite layer produce only acid magmas”. The presented deep seismic profile, which crosses the southern part of the Eastern Rhodope Paleogene Volcanic Area, offers possibilities to clarify the connection between the volcanic composition and the structure of the Earth's crust and the possible depth of the volcanic chambers. We discuss this not only on the basis of geophysical (seismic and gravity) patterns, but also using $\mathrm{Sr}$ isotopes and mineralogical data.

According to the hypothesis of Yanev et al. (1995, 1998) and Yanev (2003), the Eastern Rhodope Paleogene magmas originate as a result of the Eurasian and African plates' collision. The collision is followed by slab detachment, drops of the slab in the mantle and rising of a heat plume from the lower mantle levels. This provoked a partial melting of the heterogeneously enriched Upper mantle, metasomatized during the older (possibly Late Cretaceous) subduction, similarly to the model of Pearce et al. (1990). The origin of the Paleogene magmas from the metasomatized mantle is also supported by SrNd-Hf-Pb isotope data (Kirchenbauer et al., 2012a). The formed melt raised and accumulated in the Lower crust, where a mushroom-shaped area was formed (described in the section "Igneous bodies", Fig. 2). According to the seismic records of profile IR 1c, the Paleogene magma chambers (e.g., of the Zvezdel volcano) are located just below this area and are probably linked with them. Therefore, three levels of magma generation and storage are supposed: Upper mantle generation level (not visible on the seismic profile); mushroom-shaped body in the Lower crust; and magmatic chambers in the Upper crust.

The Paleogene volcanoes of the southern part of the Eastern Rhodope Area (Momchilgrad-Arda Volcanic Region) form a discontinuous ENE-WSW oriented belt (Fig. 9), which coincides (Yanev et al., 1983, and references therein) with the deep Burgas-Kardzhali Fault of D. Yossifov and with the direction of the NE dipping paleo-subduction zone of Shanov et al. (1987, 1992). The volcanoes form three groups in the belt (Yanev et al., 1983; Yanev and Ivanova, 2010): one with intermediate composition (Arda Group) in its middle part, respectively located in the middle of the Paleogene Depression and two with acid composition in its eastern (Maritsa Group) and western (Ustren Group) ends of the belt. South of the last group, another volcanic region, Sushitsa, is located with differentiated volcan- 


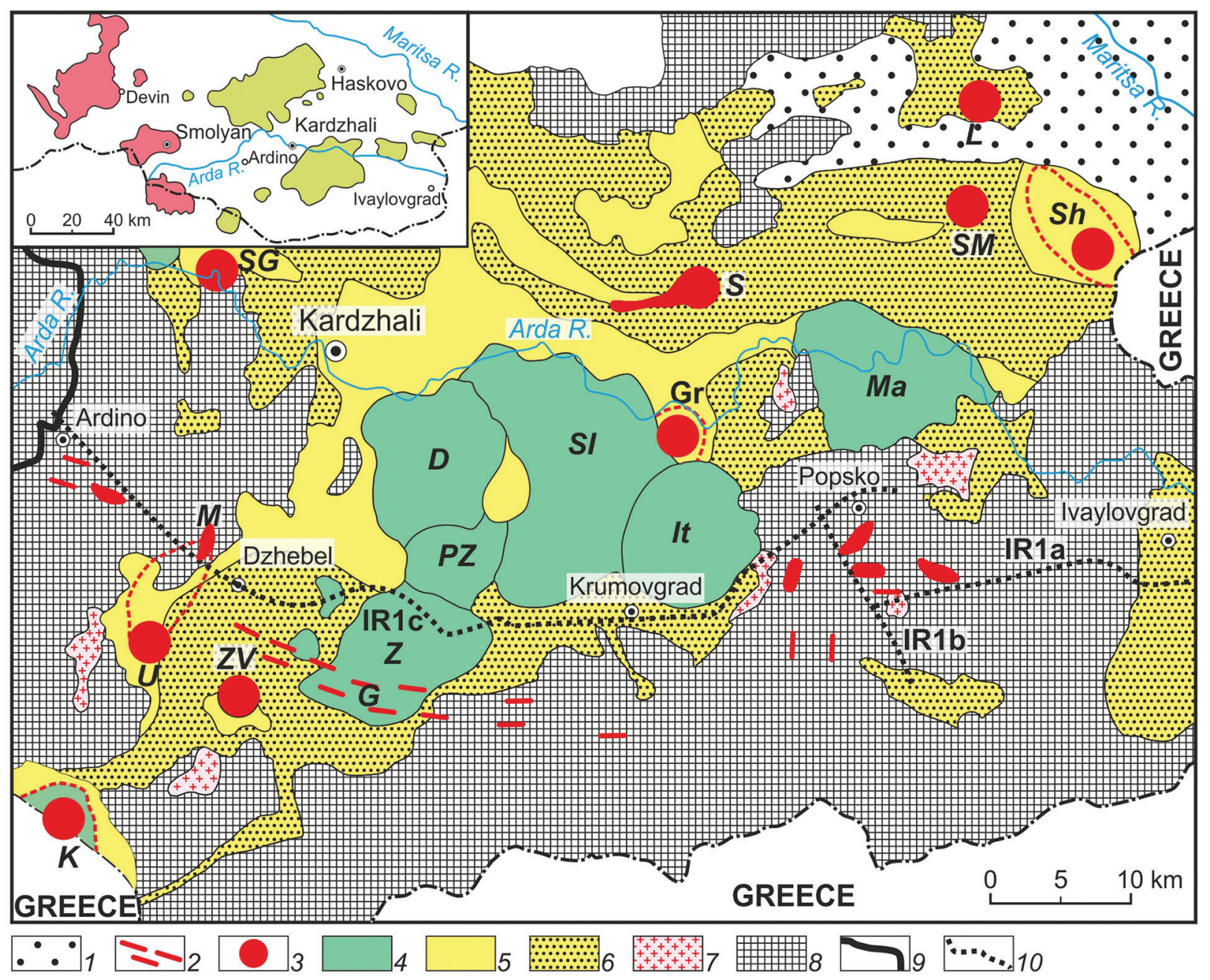

Fig. 9. Paleogene volcanics in the South-Eastern Rhodopes and position of the deep seismic profile. Legend: 1 - Neogene-Quaternary cover; Paleogene (2-5): 2 - Rupelian rhyolitic dykes and subvolcanic stocks ( $\mathrm{G}$ - Galenite dyke swarm); 3 - acid volcanoes and dome-clusters (outlined with dotted line): L - Lozen, SM - Sveta Marina, Sh - Sheinovets, S - Silen, Gr - Geren, SG - Skalna Glava, M - Mishevsko dome, U - Ustra, ZV - Zli Vrah; 4 - intermediate stratovolcanoes with acid differentiates: Ma - Madzharovo, It - Irantepe, SI - Sveti Iliya, D - Dambalak, PZ - Paleo-Zvezdel, Z - Zvezdel (K - Kushla caldera in the Sushitsa volcanic region); 5 - pyro- and epiclastics; 6 - Rupelian, Priabonian and Upper Cretaceous-Paleocene(?) sediments; 7 - Upper Cretaceous and Paleocene granitoids; 8 - metamorphic basement; 9 - Startsevo-Ardino Shear Zone; 10 -lines of the seismic profile (segments IR 1a, IR 1b and IR 1c). Inset: Eastern Rhodope acid and intermediate volcanics (in green) and Central Rhodope acid volcanics (in red).

ism and large volumes of Ostren rhyolitic ignimbrites (Georgiev et al., 2010).

\section{Arda Volcanic Group}

The Arda Group consists of large (up to $25 \mathrm{~km}$ in diameter) stratovolcanoes: Madzharovo, Irantepe, Sveti Iliya, Dambalak and Zvezdel (Figs 1, 9). Most of them have andesite and basaltic andesite composition to latite and shoshonite one (Madzarovo). They are with a few basalts, and some of them (Sveti Iliya, Dambalak) have relatively high volume of acid differentiates (trachydacites to trachyrhyolites), representing a final phase of their evolution. The ${ }^{87} \mathrm{Sr}^{86} \mathrm{Sr}_{(\mathrm{i})}$ ratio of these volcanics suggests a metasomatized mantle origin (Yanev et al., 1995, 1998) - the mean values (summarized in Kirchenbauer et al., 2012a) range from 0.707092 for high$\mathrm{K}$ andesites (Zvezdel) to 0.708063 for shoshonites (Madzharovo). The melting percentage of the metasomatized mantle is low - up to 15-20\% (Pearce and Parkinson, 1993). For the Eastern Rhodopes, the content of very high incompatible and moderately incompatible elements in the more basic vol- 
canics also shows the low to moderate degree of the melting within the pointed-out limits (Yanev, 2003). The resulting melt raised and accumulated in the Lower crust, where a mushroom-shaped area was formed (between the Varbitsa River and Krumovgrad Town - Fig. 2). The magmatic chambers of the intermediate volcanoes (e.g., Zvezdel) are located just above this area, entirely in the plates of the Upper crust, where the main part of the magma was formed by melting of the hosted magma chamber rocks. Such opinion is highlighted by Yanev et al. (1989, and references therein) for this volcano based on the high, typical crust content of some incompatible elements in the more basic rocks and its high $\mathrm{Th} / \mathrm{Yb}$ ratio. On the other hand, their low $\mathrm{Ce} / \mathrm{Yb}$ ratio indicates a possible origin from melting of amphibolites. On the basis of the presence of Ordovician-Upper Carboniferous zircons and the geochemical modeling, Raicheva (2013) argues that "contamination has played an important role in the formation of the Zvezdel magmas". The role of the crust contamination has also been highlighted and proved by other authors (e.g., Marchev et al., 1989, 1998; Nedialkov and Pe-Piper, 1998).

The only measured $\mathrm{Sr}$ isotopes in the acid differentiated rocks of the volcanoes of the Arda Group is from a trachyrhyolite of the Studen Kladenets volcano (Golobradovo perlite deposit), located on the northern periphery of the Sveti Iliya stratovolcano. It has a similar ${ }^{87} \mathrm{Sr} /{ }^{86} \mathrm{Sr}_{(\mathrm{i})}$ ratio to the intermediate volcanic rocks - 0.70766 (analyst P. Lilov). The depth of crystallization of these rocks is estimated at $11.2 \mathrm{~km}$ according to the amphibole geobarometer (Yanev and Ivanova, 2010), i.e., its magma chamber is comparable to that of intermediate magmas.

Thus, the volcanic rocks of the Arda Group, being a probable product of a three-level magma-generating process, have the geochemical and isotopic characteristics inherited by these levels. However, most of the magma is formed in the uppermost crustal chambers. Because they are located in the metamorphic plates with sub-oceanic character, their isotopic features are similar to those of the metasomatized mantle.

The two groups of acid volcanoes have a composition from dacite and trachydacite to rhyolite and trachyrhyolite, the latter prevailing. They are located along the periphery of the Paleogene Depression close to the metamorphic basement (Fig. 9) and have a different $\mathrm{Sr}$ isotope characteristic and a different depth of the magmatic chambers.

\section{Maritsa Volcanic Group}

These volcanoes of the NE end of the belt (Lozen, Sveta Marina and Sheinovets dome-cluster) are lo- cated between the southern periphery of the Harmanli block of the Thracian Terrane (Sarov, 2012) and the northern periphery of the Eastern Rhodope Dome. They have ${ }^{87} \mathrm{Sr} /{ }^{86} \mathrm{Sr}_{(\mathrm{i})}$ ratios similar to those in intermediate volcanics - from 0.707031 to 0.707819 (Ivanova et al., 2002a), and also high $\mathrm{Ba}$ and Sr contents but lower Rb one (Yanev et al., 1983, 1998). Contrary to the intermediate volcanoes of the Arda Group, however, the amphibole geobarometer of the acid volcanics indicates shallower crystallization depths and respectively shallow magmatic chambers (Yanev and Ivanova, 2010): $3.9-4.5 \mathrm{~km}$ for the Lozen volcano and 3.2-6.2 km for the Sheinovets dome-cluster. The presence of intermediate differentiates (quartz diorite porphyrites) in the Lozen volcano and evidence of mixing (Yanev and Ivanova, 2010) show a possible existence of more basic magma under the acid chambers. Probably, the individual shallow chambers of these volcanoes are located over a common molten zone of intermediate composition similar to the model of Begué et al. (2018). The high values of the gravity field (Fig. 1) in the region of the Harmanli block and the Eastern Rhodope Dome (Ivanova et al., 2002b; Trifonova et al., 2013) refer to the eventual presence also of a sub-oceanic crust beneath them, in which the intermediate magma was formed.

\section{Ustren (Dhzebel) Volcanic Group}

This group consists of the Ustra dome-cluster, containing more than 20 domes, and the Zli Vrah dome (Fig. 9), all located on the eastern slope of the Central Rhodope Dome built up by the continental crust. Only one rhyolite was analyzed (from the perlite deposit Schupenata Planina), showing a high ${ }^{87} \mathrm{Sr} /{ }^{86} \mathrm{Sr}_{(\mathrm{i})}$ ratio - 0.71182 (analyst P. Lilov, in: Yanev et al., 1998). According to the data of the seismic profile IR 1c, the slope of the CRD lies below this volcanic centre at a depth of $\sim 15 \mathrm{~km}$, and probably its magma chamber was situated therein. Another dome of this cluster, near Mishevsko Village (Figs 5, 9), contains an unusual for acid volcanics tschermakite amphibole (Yanev and Ivanova, 2010), probably included from meta-basites and/ or eclogites. The pressure of plagioclase crystallization of this rhyolite is estimated at $3.5 \mathrm{kbar}$ and depth is $13.2 \mathrm{~km}$ (according to the plagioclase geobarometer - Putirka, 2005). The presence of a tschermakite type amphibole allows us to assume that its magma chamber was located in the obducted suboceanic Plate 1, which lies here at a depth of 5-13 km (Figs 1, 5).

There is high contents of a very highly incompatible elements, such as Cs, in some volcanics located 
above the sub-oceanic crust of the MomchilgradArda Volcanic Region: in perlites (Lozen volcano and Mishevsko dome - Yanev, 1994) and in shoshonites-banakites (Madzarovo - Kirchenbauer et al., 2012a).

The magma chambers of the Central Rhodope volcanics (Fig. 9), contrary to the Eastern Rhodopean, are located in the thick continental crust of CRD (Velchev et al., 1971). They produce huge masses of only acid volcanics (ignimbrites and rhyolites) with high ${ }^{87} \mathrm{Sr} /{ }^{86} \mathrm{Sr}_{(\mathrm{i})}$ ratio - from 0.70900 to 0.70977 (Marchev et al., 1989; Harkovska et al., 1998). Based on these high isotopic ratios, the above-mentioned authors have established a positive correlation between the ${ }^{87} \mathrm{Sr} /{ }^{86} \mathrm{Sr}_{(\mathrm{i})}$ ratio and the crust thickness. However, the case of the Ustren volcanics indicates that the character, not only the thickness of the crust, plays a major role for the isotopic characteristic of the volcanics.

\section{CONCLUSIONS}

The interpretation of the deep regional seismic profile of the Eastern Rhodopes based on the surface geological bodies and tectonic structures is given for the first time. This insight into the depth structure of the Earth's crust up to the Upper mantle determines its conceptual significance, transforming the Rhodopes from an "apple of discord" into an "apple of knowledge” (Zagorchev, 2016; Ivanov, 2017).

The following conclusions can be drawn on the basis of the analysis of the deep seismic profile Ivaylovgrad-Ardino:

(1) the presence of two terranes in the Rhodopes, Rila-Western Rhodope and the Eastern Rhodope with different characteristics of the Earth's crust, continental and sub-oceanic, respectively, was confirmed;

(2) the depth of the Mohorovichich Discontinuity (Fig. 2), determined with other methods, was confirmed to be $35 \mathrm{~km}$ in the westernmost end of the IR 1c profile (under Ardino Town) and 28-30 km at its eastern end (under Popsko Village). The schizosphere/plastosphere boundary (following Scholz, 1988) is traced at depths of $24-25 \mathrm{~km}$ and rises to a depth of $22 \mathrm{~km}$ bellow Krumovgrad Town. This boundary marks the limit of penetration of most of the detected sub-vertical faults;

(3) the Upper crust of the Eastern Rhodope terrane is made up of 4 metamorphic plates with a total thickness of 22-24 km, characteriszd by a layered structure, reflecting their sub-oceanic character. The boundaries between the plates represent clear shear zones, marked by major intra-terrane tectonic events. The lower two plates (1 and 2) are obducted on the Rila-Western Rhodope Terrane, forming one obduction complex. Plate 3, following its features, is probably also is a part of this complex. The uppermost Plate 4 is thrust over them with a southward direction, covering even the obduction suture. So, the four plates build up an obduction-thrust complex. Later, the plane of obduction was reactivated as a detachment fault of the Central Rhodope Dome;

(4) two hypotheses are proposed about the possible time of the obduction: Early Carboniferous and Jurassic. It is also possible that the obduction was realized in two stages;

(5) in the seismic profiles IR 1a and IR 1b, a large dome structure, called by us the Kobilino Crypto-dome, is distinguished in Plates 1 and 2 and in the Upper mantle, which we interpret as old metamorphic core complex of mantle type. It is covered discordantly by Plate 3 at a depth of 7-7.5 km. At depth of 20-22 km in the dome's core, entirely in the plastosphere and the topmost part of the Upper mantle, the "crossed" seismic reflectance is presented;

(6) the lower two plates do not appear on the surface, but we assume that parts of them are exported as deep-cut slices, west of Ardino Town and also the Ardino "mélange", Gledka, Dobromirtsi and Golyamo Kamenyane-Yakovitsa ultramafic bodies;

(7) the upper two plates crop out on the surface: Plate 3 is revealed at the eastern end (Fig. 6) of the profile IR 1c (east of the Avren Fault) and along the whole length of IR $1 \mathrm{~b}$ and IR 1a. This area is made up of the rocks of the Pre-Rhodopean Supergroup (Belo Pole Gneiss and Tintyava Granite-gneiss formations after Kozhukharov et al., 1992) with continental characteristics, covered by the Chepelare Variegated Formation, which has a sub-oceanic character. The first refers to the Byala Reka and Divisil lithotectonic units (after Sarov, 2012) or to the so-called Lower Allochthon (after Burg et al., 1996), and the cover-forming formation - to the Krumovitsa Unit from the Upper Allochthon, i.e., Plate 3 consists of seismically indistinguishable Lower and Upper Allochthons;

(8) Plate 4 is exposed on the surface at the western end of the IR 1c profile between Ardino Town and Mishevsko Village (Fig. 5), where the rocks of the sub-oceanic Vacha Variegated and Bogutevo Plagio-gneiss formations, both of the Startsevo Lithotectonic Unit, are revealed. Herein, Plate 4 corresponds to the so-called Middle Allochthon. We can assume that the western border of the Eastern Rhodope Terrane is situated in the frame of the 
Startsevo-Ardino Shear Zone. At the eastern end of profile IR 1c, Plate 4 is situated west of the Avren Fault, where the Bogutevo Plagio-gneiss Formation (a member of the Krumovitsa Lithotectonic Unit or of the so-called Upper Allochthon) is revealed;

(9) the Eastern Rhodope Paleogene depression lies on Plate 4 (Fig. 7). This depression is limited by sub-meridional (on its eastern flank) and northeastern (in the western flank) faults with great amplitude. There are two secondary-order depressions (Dzhebel and Krumovgrad) with a thickness of the sediments of $1.5 \mathrm{~km}$ and $2 \mathrm{~km}$, respectively, separated by the Zvezdel Horst;

(10) five fault and shear zone systems (Fig. 8) with different ages that cross different plates are distinguished;

(11) in all plates (Figs 2-4) with clearly layered structure, seismicly transparent areas are visible, which we interpreted as: (i) chambers of Paleogene magmatism (e.g., under the Zvezdel volcano); and (ii) plutons with Late Cretaceous and Tertiary (?) ages. At depth of 18-20 km in the Lower crust under the central part of the Paleogene depression (approximately between the Varbitsa River and Krumovgrad Town), a mushroom-shaped area with a high degree of transparency and thickness of 8-12 km is distinguished and interpreted as a depth zone of magma generation and magma storage. Probably, the Paleogene magmatism and formation of the Eastern Rhodope depression are linked to this area of the Upper crust;

(12) the Paleogene magma chambers (e.g., the Zvezdel volcano crossed by the seismic profile IR 1c) were developed entirely in the Upper crust (especially in Plates 2 and 3). Perhaps, only a small amount of magma was formed by melting of the underlying metasomatized mantle, rising to the mushroom-shaped area in the Lower crust and to the Upper crust chambers where most of the magma is formed. Thus, three levels of magma generation and magma storage are supposed. However, because of the sub-oceanic nature of the Upper crust, both intermediate and acid magmas in the Eastern Rhodopes (Fig. 9) have isotopic characteristics similar to the metasomatized mantle. The most southwestern acid volcanics (Ustren Volcanic Group) probably have a chamber in the continental crust in the Central Rhodope Dome and they show high values of the Sr isotopic ratio similar to the Central Rhodope rhyolites;

(13) the fundamental difference between the two Rhodope terranes, continental and allochthon sub-oceanic, makes it difficult to elaborate acceptable lithostratigraphic correlations using common formations for both terranes. Due to the fact that it is not known how far the westward obduction of the Eastern Rhodope Terrane gets on the Rila-Western Rhodope one, some correlation of the so-called "Variegated" or "Imbricate Units" in the Central and Eastern Rhodopes is still possible. In contrast, however, the correlation of the Byala Reka Dome core with that of the Central Rhodope (Arda) Dome, or the Lower Allochthon (after Burg et al., 1996, and many others) and the relation of the rocks therein with the same lithostratigraphic units (Kozhukharov, 1988), as well as the separation of the Middle Allochthon on the eastern slope of the CRD, is unacceptable.

\section{Acknowledgements}

The authors would like to acknowledge the contribution of Dr A. Velev, who provided us with the migrated deep seismic profile IR 1c for geological interpretation. We would also like to thank the French Institute of Petroleum (FIP), where one of the authors, Prof. K. Khrischev, specialized under the UNESCO Program and was trained for interpretation of seismic profiling. The authors express their gratitude to Assoc. Prof. Valeri Sachanski for his help with the graphic illustrations, to Monika Hristova for improvement of the English text, and two anonimous reviewers for useful corrections of the text.

\section{REFERENCES}

Atanasov, G., Goranov, A., Belmoustakov, E. 1972. Développement paléogéographique et facial de la région au sud de Kardjali et a l'ouest de la rivière Varbitza pendant le Paléogène. Annuaire de l'Université de Sofia 64 (1), 59-79 (in Bulgarian, with French abstract).

Bazylev, B.A., Zakariadze, G.S., Zhelyazkova-Panayotova, M.D., Kolcheva, K., Oberhansli, R.E., Solov'eva, N.V. 1999. Petrology of ultrametamorphic rocks from the ophio- lite association in the crystalline basement of the Rhodope massif. Petrology 7 (2), 191-212.

Begué, F., Deering, C.D., Gravley, D.M., Kennedy, B.M., Chamberfort, I., Gualda, G.A.R., Bachmann, O. 2018. Extraction, storage and eruption of multiple isolated magma batches in the paired Mamaku and Ohakuri eruption, TaupoVolcanic Zone, New Zealand. Journal of Petrology 55, 1653-1684. 
Bončev, E. 1946. Uber die Narbenlinien in den alpinen Bau der Balkanhalbinsel. Geologica Balcanica 4 (1), 13-27 (in Bulgarian, with German abstract).

Bončev, E. 1961. Notizen über die wichtigsten Bruchlinien in Bulgarien. Travaux sur la géologie de Bulgarie, Série Stratigraphie et tectonique 2, 5-29 (in Bulgarian, with German abstract).

Bonev, N. 2006. Cenozoic tectonic evolution of the eastern Rhodope Massif (Bulgaria): Basement structure and kinematics of syn- to postcollisional extensional deformation. In: Dilek, Y., Pavlides, S. (Eds), Post-collisional Tectonics and Magmatism in the Mediterranean Region and Asia. Geological Society of America Special Paper 409, 211-235.

Bonev, N. 2015. Protoliths and metamorphic events in the highgrade metamorphic basement of the Eastern Rhodope: constraints from U-Pb zircon geochronology. Bulgarian Geological Society, National Conference with International Participation "Geosciences 2015”, Abstracts, 57-58.

Bonev, N., Marchev, P., Ovcharova, M., Moritz, R., Ulianov, A. 2010a. U-Pb LA-ICP-MS zircon geochronology of metamorphic basement and Oligocene volcanic rocks from the SE Rhodopes: inferences of the geological history of the Eastern Rhodope crystalline basement. Bulgarian Geological Society, National Conference with International Participation “Geosciences 2010”, Abstracts, 115-116.

Bonev, N., Moritz, R., Márton, I., Chiaradia, M., Marchev, P. 2010b. Geochemistry, tectonics, and crustal evolution of basement rocks in the Eastern Rhodope Massif, Bulgaria. International Geology Review 52 (2-3), 269-297.

Bonev, N., Spikings, R., Moritz, R., Marchev, P. 2010c. The effect of early Alpine thrusting in late-stage extensional tectonics: Evidence from the Kulidzhik nappe and the Pelevun extensional allochthon in the Rhodope Massif, Bulgaria. Tectonophysics 488, 256-281.

Bonev, N., Spikings, R., Moritz, R., Marchev, P., Collings, D. 2013a. ${ }^{40} \mathrm{Ar} /{ }^{39} \mathrm{Ar}$ age constraints on the timing of Tertiary crustal extension and its temporal relation to ore-forming and magmatic processes in the Eastern Rhodope Massif, Bulgaria. Lithos 180-181, 264-278.

Bonev, N., Ovtcharova-Schaltegger, M., Moritz, R., Marchev, P., Ulianov, A. 2013b. Peri-Gondwanan Ordovician crustal fragments in the high-grade basement of the Eastern Rhodope Massif, Bulgaria: evidence from U-Pb LA-ICP-MS zircon geochronology and geochemistry. Geodinamica Acta, doi:10.1080/09853111.2013.858942.

Bonev, N., Filipov, P., Raicheva, R., Moritz, R. 2019. Timing and tectonic significance of Paleozoic magmatism in the Sakar unit of the Sakar-Strandzha Zone, SE Bulgaria. International Geology Review 61 (16), 1957-1979.

Botev, E., Spassov, E. 1989. Main features of the lithosphere in the central part of the Balkan region. Gerlands Beiträge zur Geophysik 132 (5), 388-397.

Botev, E., Burmakov, Ju. A., Treussov, A.V., Vinnik, L.P. 1988. Crust and upper-mantle inhomogeneities beneath the central part of the Balkan region. Physics of the Earth and Planetary Interiors 51, 198-210.

Boyanov, I., Goranov, A. 2001. Late Alpine (Paleogene) superimposed depressions in the parts of Southeast Bulgaria. Geologica Balcanica 31 (3-4), 3-36.

Boykova, A. 1999. Moho discontinuity in central Balkan Peninsula in the light of the geostatistical structural analysis. Physics of the Earth and Planetary Interiors 114, 49-58.

Brun, J.-P. Sokoutis, D., Tirel, C., Gueydan, F., van den Driessche, J., Beslier, M.-O. 2018. Crustal versus mantle core complexes. Tectonophysics 746, 22-45.

Burg, J.-P. 2011. Rhodope: from Mesozoic convergence to Cenozoic extension. Review of petro-structural data in the geochronological frame. In: Skourtsos, E., Lister, G. S. (Eds), The Geology of Greece. Journal of the Virtual Explorer 39, paper 1, doi: 10.3809/jvirtex.2011.00270.

Burg, J.-P., Ricou, L.-J., Ivanov, Z., Godfriaux, I., Dimov, D., Klain, L. 1996. Syn-metamorphic nappe complex in the Rhodope Massif. Structure and kinematics. Terra Nova 8, 6-15.

Carrigan, C., Mukasa, S., Haydoutov, I., Kolcheva, K. 2003. Ion microprobe $\mathrm{U}-\mathrm{Pb}$ zircon ages of pre-Alpine rocks in the Balkan, Sredna Gora, and Rhodope terranes of Bulgaria: Constraints on Neoproterozoic and Variscan tectonic evolution. Journal of Czech Geological Society. Abstracts. International Conference "Geology without Frontiers: Magmatic and Metamorphic Evolution of Central European Variscides" 48 (1-2), 32-33.

Cherneva, Z., Ovtcharova, M., von Quadt, A., Kolcheva, K., Stancheva, E., Sarov, S., Peytcheva, I. 2002. Monazite and zircon U-Pb ages of migmatites from the Arda River valley, Central Rhodopian Dome, Bulgaria. Proceedings of the Annual Scientific Conference of the Bulgarian Geological Society, 20-22.

Cherneva, Z., Georgieva, M., Gerdjikov, I., Grozdev, V., Stancheva, E. 2014. New data on mid-Mesozoic migmatization in the Central Rhodope. Bulgarian Geological Society, National Conference with International Participation “Geosciences 2014”, Abstracts, 13-14.

Dabovski, C., Boyanov, I., Khrischev, K., Nikolov, T., Sapunov, I., Yanev, Y., Zagorchev, I. 2002. Structure and Alpine evolution of Bulgaria. Geologica Balcanica 32 (2-4), 9-15.

Dachev, H. 1988. Structure of the Earth Crust in Bulgaria. Tehnika, Sofia, 334 pp. (in Bulgarian, with English abstract).

Daieva, L.-A., Haydoutov, I., Pristavova, S. 2007. Geochemical correlation of metabasic rocks from Central and East Rhodopes, Bulgaria. Geochemistry, Mineralogy and Petrology 45, 109-118.

Dinter, D., Royden, L. 1993. Late Cenosoic extention in northeastern Greece: Strymon valley detachement system and Rhodope metamorphic core complex. Geology 21, 45-48.

Gautier, P., Bosse, V., Cherneva, Z., Didier, A., Gerdjikov, I., Tiepolo, M. 2017. Polycyclic alpine orogeny in the Rhodope metamorphic complex: the record in migmatites from the Nestos shear zone (N. Greece). Bulletin de la Société géologique de France, BSGF-Earth Sciences Bulletin 7, 188 (6), p. 36, doi: 10.1051/bsgf/2017195.

Georgiev, S., Yordanov, B., Nedyalkov, R. 2010. Petrological and petrochemical characteristics of the rocks of the Kushla caldera, East Rhodope massif. XIX Congress CBGA, Thessaloniki, Extended Abstracts, 233-243.

Georgiev, V. 2002. Origin and initial evolution of the Momchilgrad volcanotectonic depression (Eastern Rhodopes). Review of the Bulgarian Geological Society 63 (1-3), 99106 (in Bulgarian, with English abstract).

Georgieva, M. 2014. Late Jurassic metamorphism of highgrade metamorphic rocks from Krumovitza/Kimi unit, East Rhodope, Bulgaria - SHRIMP U-Pb dating of zircons. Bulgarian Geological Society, National Conference with International Participation "Geosciences 2014", Abstracts, 19-20.

Gochev, P. 1982. On the problem of alpine zoning, vergence and other features of nappes in Bulgaria and the eastern part of the Balkan Peninsula. In: Mahel, M. (Ed.). Alpine Structural Elements of Carpathian-Balkan-Caucasus-Pamir Orogen Zone. Veda, Bratislava, 75-93.

González-Jiménez, J.M., Locmelis, M., Belousova, E., Griffin, W.L., Gervilla, F., Kerestedjian, Th., O’Reilly, S.-Y., 
Pearson, N.J., Sergeeva, I. 2015. Genesis and tectonic implications of podiform chromitites in the metamorphosed ultramafic massif of Dobromirtsi (Bulgaria). Gondwana Research 27, 555-574.

Goranov, A., Atanasov, G. 1992. Lithostratigraphy and formation conditions of Maastrichtian-Palaeocene deposit in Krumovgrad District. Geologica Balcanica 22 (3), 71-82.

Gulmezova, E., Velev, A. 1999. Data processing of the deep reflection seismic profiles in South Bulgaria. $2^{\text {nd }}$ Balkan Geophysical Congress and Exhibition. Istanbul, Book of Abstracts, 198-199.

Hansen, T.M., Balling, N. 2004. Upper-mantle reflectors: modelling of seismic wavefield characteristics and tectonic implications. Geophysical Journal International 57, 664-682.

Harkovska, A., Marchev, P., Machev, Ph., Pecskay, Z. 1998. Paleogene magmatism in the Central Rhodope area, Bulgaria. A review and new data. Acta Vulcanologica 10 (2), 199-216.

Haydoutov, I., Kolcheva, K., Daieva, L.-A., Savov, I., Carrigan, C. 2004. Island arc origin of the variegated formations from the East Rhodope, Bulgaria - implications for the evolution of the Rhodope Massif. Ofioliti 29 (2), 145-157.

Hegazy, T., AlRegib, Gh. 2014. Texture attributes for detecting salt bodies in seismic data. Society of Exploration Geophysicists Annual Meeting, Denver, Expanded Abstracts, 14551459, DOI: https://doi.org/10.1190/segam2014-1512.1.

Itoh, Y., Iwata, T., Takemura, K. 2017. Three-dimensional architecture of the Median Tectonic Line in Southwest Japan based on detailed reflection seismic and drilling surveys. In: Itoh, Y. (Ed.), Evolutionary Models of Convergent Margins - Origin of their Diversity. IntechOpen, Osaka Prefecture University, Japan, DOI: 10.5772/67434.

Ivanov, Ž. (Ed.). 2000. Structure, Alpine Evolution and Mineralizations of the Central Rodopes Area (South Bulgaria). Guide to excursion B, ABCD-GEODE workshop, Borovets, Bulgaria, 50 pp.

Ivanov, Ž. 2017. Tectonics of Bulgaria. Sofia University "St Kliment Ohridski”, 332 pp. (in Bulgarian).

Ivanov, Ž., Moskovski, S., Kolceva, K. 1979. Basic features of the structure of the central parts of the Rhodope massif. Geologica Balcanica 9 (1), 3-50 (in Russian, with English abstract).

Ivanova, R., Kamenov, G., Yanev, Y. 2002a. Sr, Nd, and Pb isotopic chemistry of rhyolites from the Eastern Rhodopes, Bulgaria. American Geophysical Union Fall Meeting, Supplementary Abstract 83 (47), V62B-1413.

Ivanova, R., Mircheva, L., Kehayov, D. 2002b. Elaboration of gravimetric map of Bulgaria in scale 1:100 000 and Catalogue of the gravimetric points on the base of found materials. Unpublished repport, National Geological Found, Ministry of Energetic (in Bulgarian).

Jahn-Awe, S., Pleuger, J., Frei, D., Georgiev, N., Froitzheim, N., Nagel, T. J. 2012. Time constraints for low-angle shear zones in the Central Rhodopes (Bulgaria) and their significance for the exhumation of high-pressure rocks. International Journal of Earth Sciences 101, 1971-2004.

Jones, I. F., Davison, I. 2014. Seismic imaging in and around salt bodies. Interpretation 2 (4), SL1-SL20, DOI: http://dx. doi.org/10.1190/INT-2014-0033.1.

Khristchev, Kh., Shanov, S. 2017. Geological interpretation of the regional deep seismic reflection profile in Eastern Rhodope Mountain (South Bulgaria). $9^{\text {th }}$ Congress of the Balkan Geophysical Society, Antalya, Extended Abstracts.

Khristchev, Kh., Shanov, S., Pristavova, S., Yanev, Y. 2017. Deep seismic profile in the Rhodopes (S. Bulgaria) and its conceptual significance. Bulgarian Geological Society, $\mathrm{Na}$ - tional Conference with International Paricipation "Geosciences 2017", Abstracts, 77-78.

Kirchenbauer, M., Munker, C., Schuth, S., Garbe-Schonberg, D., Marchev, P. 2012a. Tectonomagmatic constraints on the sources of Eastern Mediterranean K-rich lavas. Journal of Petrology 53, 27-65.

Kirchenbauer, M., Pleuger, J., Jahn-Awe, S., Nagel, T. J., Froitzheim, N., Fonseca, R. O. C., Munker, C. 2012b. Timing of high-pressure metamorphic events in the Bulgarian Rhodopes from Lu-Hf garnet geochronology. Contribution to Mineralogy and Petrology 163, 897-921.

Kolcheva, K., Zeljazkova-Panajotova, M., Dobrecov, N., Stojanova, V. 1986. Eclogites in Central Rhodope metamorphic group. Geochemistry, Mineralogy and Petrology 20-21, 130-144.

Kozhoukharov, D. 1988. Precambrian in the Rhodope massif. Lithostratigraphy. In: Zoubek, V. (Ed.), Precambrian in Younger Fold Belts - European Variscides, the Carpathians and Balkans. John Wiley \& Sons, Chichester, 726-746.

Kozhoukharov, D., Boyanov, I., Goranov, A., Yanev, Y., Shiliafova, J., Russeva. M. 1989. Geological map of Bulgaria, scale 1:100 000, Kardjali map sheet. Geology and Mineral Resources Committee, Enterprise of Geophysical Survey and Geological Mapping, Sofia.

Kozhoukharov, D., Boyanov, I., Goranov, A., Kozhoukharova, E. 1992. Geological map of the Republic of Bulgaria, scale 1:100 000, Krumovgrad-Sape map sheet. Geology and Mineral Resources Committee, Enterprise of Geophysical Survey and Geological Mapping, Sofia.

Kozhuharova, E. 1984. The origin and structural position of the serpentinized ultrabasites of the Precambrian ophiolite association in the Rhodope massif. I. Geological position and composition of the ophiolite association. Geologica Balcanica 14 (4), 9-36 (in Russian with an English abstract).

Macheva, L., Kolcheva, K. 1992. Metagranitoids from Eastern Rhodopes - occurrences and main features. Comptes Rendus de l'Académie bulgare des Sciences 45 (6), 63-66.

Macheva, L., Peytcheva, I., von Quadt, A., Kolcheva, K., Tacheva, E. 2018. Eclogites from Biala Reka-Kechros metamorphic dome, E. Rhodopes (Bulgaria): petrological features and protolithic age. XXI International Congress CBGA, Salzburg, Abstracts, p. 155.

Marchev, P., Lilov, P., Amov, P., Arnaudov, V., Yordanov, Y. 1989. Major, trace elements and isotopic $(\mathrm{Sr}, \mathrm{Pb})$ zonality in the Eocene-Oligocene Rhodope magmatic zone. Evidence for subduction processes and crustal influence. XIV Congress CBGA, Sofia, Extended Abstracts, 226-229.

Marchev, P., Rogers, G., Conrey, R., Quick, J., Vaselli, O., Raicheva, R. 1998. Paleogene orogenic and alkaline basic magmas in the Rhodope zone: relationships, nature of magma sources, and role of crustal contamination. Acta Vulcanologica 10 (2), 217-232.

Marchev, P., Raicheva, R., Downes, H., Vaselli, O., Chiaradia, M., Moritz, R. 2004a. Compositional diversity of EoceneOligocene basaltic magmatism in the Eastern Rhodopes, SE Bulgaria: implications for genesis and tectonic setting. Tectonophysics 393, 301-328.

Marchev, P., Singer, B., Jelev, D., Hasson, S., Moritz, R., Bonev, N. 2004b. The Ada Tepe deposit: a sediment-hosted and detachment fault-controlled low-sulfidation gold mineralization in the Eastern Rhodopes, SE Bulgaria. Schweizerische Mineralogische und Petrographische Mitteilungen 84, 59-78.

Marchev, P., Arai, S., Vaselli, O. 2006a. Cumulate xenoliths series in the Krumovgrad alkaline basaltic and lamprophy- 
ric dykes: Evidence for the existence of layered plutons under the Eastern Rhodope metamorphic core-complexes, Bulgaria. In: Dilek, Y., Pavlides, S. (Eds), Post-collisional Tectonics \& Magmatism in the Eastern Mediterranean Region. Geological Society of America, Special Paper 409, 237-258.

Marchev, P., von Quadt, A., Peytcheva, I., Ovtcharova, M. 2006b. The age and origin of the Chuchuliga and Rozino granites, Eastern Rhodopes. Bulgarian Geological Society, National Conference with International Participation "Geosciences 2006", Abstracts, 213-216.

Mavrudchiev, B. 1992. Paleogene Plutonism in the Eastern Rhodopes. Doctor Thesis, Sofia University "St. Kliment Ohridski” 439, pp. (in Bulgarian, unpublished).

Nedialkov, R. 2010. Preliminary results of xenolites in basaltic andesite subvolcanic body in the vicinity of Krumovgrad, Eastern Rhodopes, Bulgaria. In: Scientific Annals of the School of Geology. XIX Congress of CBGA, Special volume 100, Aristotle University of Thessaloniki, Faculty of Sciences, 299-306.

Nedialkov, R., Mavroudchiev, B. 1995. Geochemical and mineralogical peculiarities of the Zvezdel pluton (East Rhodopes, Bulgaria). Geological Society of Greece Special Publication 4, 561-565.

Nedialkov, R., Pe-Piper, G. 1998. Petrology of the volcanism in the southeastern part of the Momchilgrad-Arda volcanic region, southeastern Bulgaria. Acta Vulcanologica 10 (2), 243-253.

Ovtcharova, M. 2005. Petrology, Geochronology and Isotopic Studies of the Metagranitoids of the Eastern Part of Madan-Davidkovo Dome. PhD Thesis, Sofia University "St Kliment Ohridski”, 255 pp. (in Bulgarian, unpublished).

Ovtcharova, M., Cherneva, Z., von Quadt, A., Peytcheva, I. 2002. Migmatitic geochronology and geochemistry - a key to understanding the exhumation of the Madan Dome (Bulgaria). Geochimica et Cosmochimica Acta 66 (Supplement 1), p. 573.

Pearce, J.A., Parkinson, I.J. 1993. Trace element models for mantle melting: Application to volcanic arc petrogenesis. In: Prichard, H.M., Alabaster, T., Harris, N.B.W., Neary, C.R. (Eds), Magmatic Processes and Plate Tectonics. Geological Society, London, Special Publication 76, 373-403.

Peytcheva, I., von Quadt, A. 1995. U-Pb zircon dating of metagranites from Byala Reka region in the East Rhodopes, Bulgaria. Geological Society of Greece Special Publications 4, 637-642.

Peytcheva, I., von Quadt, A., Ovtcharova, M., Handler, R., Neubauer, F., Salnikova, E., Kostitsyn, Y., Sarov, S., Kolcheva, K. 2004. Metagranitoids from the eastern part of the Central Rhodopean Dome (Bulgaria): U-Pb, Rb-Sr and ${ }^{40} \mathrm{Ar} /{ }^{39} \mathrm{Ar}$ timing of emplacement and exhumation and isotope-geochemical features. Mineralogy and Petrology 82, 1-31.

Popov, P., Yanev, Y., Stefanov, N., Bahneva, D. 1972. Dobromirtsi fault system. Annuaire de l'Ecole Supérieure des Mines et de Géologie 11 (2), 61-75 (in Bulgarian, with English abstract).

Pristavova, S. 1995. Evolution of the Metamorphism in the Precambrian Rocks from Madan-Davidkovo Dome, Central Rhodope. PhD Thesis, Geological Institute, Bulgarian Academy of Sciences, 158 pp. (in Bulgarian, unpublished).

Pristavova, S. Daieva, L-A. 1998. New data on the geochemistry of gabbronorites from the eastern marginal part of Madan-Davidkovo Structure, Central Rhodope. Geochemistry, Mineralogy and Petrology 35, 47-54.

Putirka, K. D. 2005. Igneous thermometers and barometers based on plagioclase + liquid equilibria: Tests of some ex- isting models and new calibrations. American Mineralogist 90, 336-346.

Raicheva, R. 2013. Role of the Processes of Magma Mixing in the Petrological Evolution of the Zvezdel Palaeovolcano. $\mathrm{PhD}$ Thesis, Geological Institute, Bulgarian Academy of Sciences, 181 pp. (in Bulgarian, unpublished).

Sarov, S. 2012. Lithotectonic subdivision of the metamorphic rocks in the area of Rila and Rhodope Mountains - results from geological mapping at scale 1:50 000. International conference "The School of Prof. Zhivko Ivanov", Sofia, Extended abstracts, 43-47.

Sarov, S., Cherneva, Z., Kocheva, K., Voinova, E., Gerdjikov, I. 2004. Lithotectonic subdivision of the metamorphic rocks from the eastern parts of the Central Rhodope extension structure. Review of Bulgarian Geological Society 65 (1-3), 101-106.

Sarov, S., Yordanov, B., Georgiev, S., Valkov, V., Balkanska, E., Grozdev, V., Marinova, R., Markov, N. 2008. Explanatory note of Geological Map of Bulgaria in scale 1:50 000, Mandrica and Microderion map sheet. Ministry of Envorenment and Wather, Bulgarian Geological Survey, Sofia, 64 pp.

Scholtz, C. 1988. The brittle-plastic transition and the depth of seismic faulting. Geologische Rundschau 77, 319-328.

Scholz, C. 2002. The Mechanics of Earthquakes and Faulting, $2^{\text {nd }}$ ed. Cambridge University Press, Cambridge, New York, Melbourne, $471 \mathrm{pp}$.

Shanov, S., Riazkov. H., Bojanov, I. 1987. The Rhodope region in the light of the new geophysical interpretations. First Bulgarian-Greek Symposium on Geology and Physic Geography of the Rhodope Massif, Abstracts, 19-20.

Shanov, S.B., Spassov, E., Georgiev, T. 1992. Evidence for the existence of a paleosubduction zone beneath the Rhodopean massif (Central Balkans). Tectonophysics 206 (3-4), 307-314.

Stampfli, G.M., Hochard, C. 2009. Plate tectonics of the Alpine realm. Geological Society, London, Special Publication 327, 89-11.

Stampfli, G.M., von Raumer, J.F., Borel, G.D. 2002. Paleozoic evolution of pre-Variscan terranes: From Gondwana to the Variscan collision. Geological Society of America, Special Paper 364, 263-280.

Stoykov, S., Mavrudchiev, B. 1997. Petrology of Chuchuliga I-type granitoides, Eastern Rhodopes. Geochemistry, Mineralogy and Petrology 32, 101-116.

ten Brink, U.S., Zhang, J., Brocher, Th.M., Okaya, D.A., Klitgord, K.D., Fuis, G.S. 2000. Geophysical evidence for the evolution of the California Inner Continental Borderland as a metamorphic core complex. Journal of Geophysical Research 105 (B3), 5835-5857.

Trifonova, P., Solakov, D., Simeonova, S., Metodiev, M., Stavrev, P. 2013. Regional pattern of the earth's crust dislocations on the territory of Bulgaria inferred from gravity data and its recognition in the spatial distribution of seismicity. Pattern Recognition in Physics 1, 25-36, doi: 10.5194/prp-1-25-2013.

Velchev, Tz., Dimitrov, R., Mavroudchiev, B.D. 1971. On the structure in depth of the East Rhodopa block and Central Rhodopa fault zone in depth. Comptes Rendus de l'Académie bulgare des Sciences 24, 1231-1234 (in Russian).

Velev, A. 1996. Deep seismic profiling of the Earth's crust along the regional profile Ivaylovgrad-Ardino. Bulgarian Geophysical Journal 22 (1), 91-107 (in Bulgarian).

Velev, A., Yanev, Y., Boyanov, I. 1995. Crustal structure of the East Rhodope Mts according to the deep seismic profile Ardino-Ivaylovgrad. Unpublished repport, National Geological Fond, Ministry of Energetic (in Bulgarian). 
Velev, A., Boyanov, I., Yanev, Y. 1996. Results of deep seismic reflection profiling across the East Rhodopes, South Bulgaria. PANCARDI Workshop "Dynamics of the Pannonian-Carpathian-Dinaride System”, Abstracts.

Velev, V., Yanev, Y. 1966. Solid bitumens from hydrothermal zones near the village of Ptichar, the country of Kurdjaly. Annuaire de l'Université de Sofia 59 (1), 189-204 (in Bulgarian, with English abstract).

Volvovski, I.S., Dachev, H., Popova, O.G., Velev, A., Babinets, V.A., Natroshvili, L.T. 1985. Structure of the Earth's crust of Bulgaria (on Petrich-Nicopol DSS line). Bulletin of Moscow Society of Naturalists, Geological Series 60 (4), 38-47 (in Russian).

von Quadt, A., Peytcheva, I., Sarov, S., Liati, A. 2010. Late Cretaceous subduction and magmatism in the Rhodopes: geochronological and isotope-geochemical evidence. Bulgarian Geological Society, National Conference with International Participation "Geosciences 2010”, Abstracts, 13-14.

Yanev, Y. 1994. Cesium-bearing perlites in the Borovitza caldera, Eastern Rhodopes (Bulgaria). Petrology 2 (1), 96-113.

Yanev, Y. 2003. Mantle source of the Paleogene collision-related magmas of the Eastern Rhodopes (Bulgaria) and Western Thrace (Greece): Characteristics of the mafic magmatic rocks. Neues Jahrbuch für Mineralogie, Abhandlungen 178 (2), 131-151.

Yanev, Y., Ivanova, R. 2008/2009. Paleogene ultrapotassic volcanic rocks of the Eastern Rhodopes, South Bulgaria: Petrology, mineralogy and origin. Acta Vulcanologica 20 21 (1-2), 99-122.

Yanev, Y., Ivanova, R. 2010. Mineral chemistry of the collision-related acid Paleogene volcanic rocks of the Eastern Rhodopes, Bulgaria. Geochemistry, Mineralogy and Petrology 48, 39-65.

Yanev, Y. Karadjova, B., Andreev, A. 1983. Distribution of alkalis and genesis of the acid volcanic rocks in part of East- ern Rhodope Paleogene depression. Geologica Balcanica 13 (3), 15-44 (in Russian, with English abstract).

Yanev, Y., Mavroudchiev, B., Nedyalkov, R. 1989. Paleogene collision-related basalts and basaltic andesites in the Eastern Rhodopes, Bulgaria. Journal of Volcanology and Geothermal Research 37, 187-202.

Yanev, Y. Innocenti, F., Manetti, P., Serri, G. 1995. Paleogene collision magmatism in eastern Rhodopes (Bulgaria)-Western Thrace (Greece): Temporal migration, petrochemical zoning and geodynamic significance. $X V$ Congress $C B G A$, Athens, Extended Abstracts, 578-583.

Yanev, Y., Innocenti, F., Manetti, P., Serri, G. 1998. Upper Eocene-Oligocene collision-related volcanism in eastern Rhodopes (Bulgaria)-Western Thrace (Greece): Petrogenetic affinity and geodynamic significance. Acta Vulcanologica 10 (2), 279-292.

Yossifov, D., Tsvetkov, A., Grigorova, E., Stavrev, P., Nedev, V. 1980. Main features in the structure of the Earth's crust in Rhodope massif. Geotectonics, Tectonophysics and Geodynamics 12, 27-45 (in Bulgarian, with English abstract).

Zagorchev, I. 2015. Polyphase tectonometamorphism in Bulgaria: Some alternative interpretations and ideas. Bulgarian Geological Society, National Conference with International Participation “Geosciences 2015”, Abstracts, 99-100.

Zagorchev, I. 2016. The Rhodope massif - apple of discord or apple of knowledge for Bulgarian geology. Journal of the Bulgarian Academy of Sciences 4, 3-13 (in Bulgarian).

Zagorchev, I., Balica, C., Balintoni, I. 2015. Repeated crustal melting and ductile flow: possible major mechanisms of Rhodope evolution. Comptes rendus de l'Académie bulgare des Sciences 68, 1401-1414.

Zdraveva, O., Velev, A., Gjulmezova, E., Petkova, L. 1996. Deep seismic reflection profiling along Eastern Rhodopes for crust structure investigation. First Congress of the Balkan Geophysical Society, Abstracts. Athens, 378-379. 